\title{
Molecular Rationale of Insect-Microbes Symbiosis-From Insect Behaviour to Mechanism
}

\author{
Sujata Singh ${ }^{1,2,+}$, Archana Singh ${ }^{2, \dagger}$, Varsha Baweja ${ }^{1,3}$, Amit Roy ${ }^{4,5} \mathbb{D}$, Amrita Chakraborty ${ }^{4, *}$ (D) \\ and Indrakant Kumar Singh $1,3, *$ (D)
}

1 Molecular Biology Research Lab, Department of Zoology, Deshbandhu College, University of Delhi, Kalkaji, New Delhi 110019, India; sujatasingh@db.du.ac.in (S.S.); vbaweja@db.du.ac.in (V.B.)

2 Department of Botany, Hansraj College, University of Delhi, New Delhi 110007, India; archanasingh@hrc.du.ac.in

3 DBC i4 Center, Deshbandhu College, University of Delhi, Kalkaji, New Delhi 110019, India

4 EVA 4.0 Unit, Faculty of Forestry and Wood Sciences, Czech University of Life Sciences, Kamýcká 129, Suchdol, 16521 Prague 6, Czech Republic; roy@fld.czu.cz

5 Excelentní Tým pro Mitigaci (ETM), Faculty of Forestry and Wood Sciences, Czech University of Life Sciences, Kamýcká 129, Suchdol, 16521 Prague 6, Czech Republic

* Correspondence: chakraborty@fld.czu.cz (A.C.); iksingh@db.du.ac.in (I.K.S.)

+ These authors contributed equally as the first author.

Citation: Singh, S.; Singh, A.; Baweja, V.; Roy, A.; Chakraborty, A.; Singh,

I.K. Molecular Rationale of Insect-Microbes Symbiosis-From Insect Behaviour to Mechanism. Microorganisms 2021, 9, 2422. https://doi.org/10.3390/ microorganisms 9122422

Academic Editor: Patricia Luis

Received: 26 October 2021

Accepted: 21 November 2021

Published: 24 November 2021

Publisher's Note: MDPI stays neutral with regard to jurisdictional claims in published maps and institutional affiliations.

Copyright: (c) 2021 by the authors. Licensee MDPI, Basel, Switzerland. This article is an open access article distributed under the terms and conditions of the Creative Commons Attribution (CC BY) license (https:/ / creativecommons.org/licenses/by/ $4.0 /)$.

\begin{abstract}
Insects nurture a panoply of microbial populations that are often obligatory and exist mutually with their hosts. Symbionts not only impact their host fitness but also shape the trajectory of their phenotype. This co-constructed niche successfully evolved long in the past to mark advanced ecological specialization. The resident microbes regulate insect nutrition by controlling their host plant specialization and immunity. It enhances the host fitness and performance by detoxifying toxins secreted by the predators and abstains them. The profound effect of a microbial population on insect physiology and behaviour is exploited to understand the host-microbial system in diverse taxa. Emergent research of insect-associated microbes has revealed their potential to modulate insect brain functions and, ultimately, control their behaviours, including social interactions. The revelation of the gut microbiota-brain axis has now unravelled insects as a cost-effective potential model to study neurodegenerative disorders and behavioural dysfunctions in humans. This article reviewed our knowledge about the insect-microbial system, an exquisite network of interactions operating between insects and microbes, its mechanistic insight that holds intricate multi-organismal systems in harmony, and its future perspectives. The demystification of molecular networks governing insect-microbial symbiosis will reveal the perplexing behaviours of insects that could be utilized in managing insect pests.
\end{abstract}

Keywords: insect symbiosis; holobiont; gut microbiome; arthropod vector; host immunity; nutrition provisioning; detoxification; omics technology

\section{Introduction}

The American author Frederick Lenz beautifully said, "Symbiosis is a much higher reflection of intelligent life." He termed a symbiotic relationship as reciprocity between two people governed by specific terms under certain conditions for a balanced relationship. It profoundly describes the complexity and diversity of the lifelong association of a microbial community with its eukaryotic hosts. The advancement in sequencing and PCR-based technologies has dramatically expanded our insight into microbial systems. Notwithstanding, the failure to cultivate these microbes in vitro impedes the dissection of the functional aspects of these interactions. This is primarily the reason behind the elusiveness of microbial consortiums [1,2]. Compared to higher eukaryotes, which harbour a panoply of commensal organisms, less-diverse microbial symbionts colonize insects. This enables investigators to focus on the contribution of individual symbionts to their 
host and project insects as an economical and excellent model system for interdisciplinary research [3-5]. The interdisciplinary research involving microbiology, neurosciences, and medicine holds a promising future for elucidating the role of gut symbionts in neurological and behavioural disorders (such as neurodegenerative disorders and autism spectrum disorders) and finding their probiotic solutions [6].

Furthermore, dysbiosis reduces the host fitness and inflicts autoimmune diseases such as rheumatoid arthritis or type I diabetes [7,8]. It is apparent that the host-microbe interaction is intricate, and any disturbance could have far-reaching impacts than hitherto appreciated. In insect-plant interactions, mutualistic symbiosis effects are considerably subtler [9]. Microbial mutualists often shape the diet breadth of insect hosts via nutrient provisioning and breaking down toxins, host adaptations to environmental perturbations, host behaviours, growth and development, mating, reproduction, plant physiology favouring insect hosts, and defending hosts against predators [10-13]. However, the gut bacteria have prioritised their role. Nutrient provisioning is the most crucial role, other than digestion and detoxification [14]. The symbiotic microbiome maintains and/or enhances the host immune system in insects serving as disease vectors. It also influences its vector competence [15]. As insects are prevalent human disease vectors and agricultural and forest pests, a better understanding of insect pests as a holobiont is of utmost importance for formulating sustainable management strategies (Table 1).

Table 1. A glimpse of symbiotic relationships in insects.

\begin{tabular}{|c|c|c|c|c|c|}
\hline $\begin{array}{c}\text { Bacterial } \\
\text { Symbionts }\end{array}$ & Insect Host & $\begin{array}{l}\text { Niche Location } \\
\text { within Host }\end{array}$ & Transmission Mode & Interaction Benefits & References \\
\hline $\begin{array}{l}\text { Ishikawaella } \\
\text { capsulate } \\
\text { (Obligate } \\
\text { mutualist) }\end{array}$ & $\begin{array}{l}\text { Megacopta } \\
\text { punctatissima } \\
\text { (Plataspid } \\
\text { stinkbugs) }\end{array}$ & $\begin{array}{l}\text { Extracellular } \\
\text { midgut }\end{array}$ & $\begin{array}{c}\text { Inheritable and } \\
\text { transmitted through } \\
\text { a capsule }\end{array}$ & $\begin{array}{l}\text { Enhance pest status of the } \\
\text { insect host. } \\
\text { Microbe compensates for } \\
\text { nutritional deficiency of } \\
\text { host diet by supplying } \\
\text { essential amino acids. }\end{array}$ & {$[16,17]$} \\
\hline $\begin{array}{l}\text { Regiella insecticola } \\
\text { (Facultative } \\
\text { commensal) }\end{array}$ & $\begin{array}{l}\text { Acyrthosiphon } \\
\text { pisum (Aphid) }\end{array}$ & $\begin{array}{l}\text { Bacteriocytes, } \\
\text { Haemolymph }\end{array}$ & $\begin{array}{l}\text { Inheritable and } \\
\text { transmitted via } \\
\text { Transovarial }\end{array}$ & $\begin{array}{l}\text { Influence host plant range; } \\
\text { survival, and reproduction } \\
\text { on clover of insect host. }\end{array}$ & [18] \\
\hline $\begin{array}{l}\text { Wolbachia sp. } \\
\text { (Facultative } \\
\text { parasite) }\end{array}$ & Diabrotica virgifera & $\begin{array}{l}\text { Bacteriocytes, } \\
\text { extracellularly } \\
\text { scattered }\end{array}$ & $\begin{array}{c}\text { Inheritable and } \\
\text { transmitted via } \\
\text { Transovarial }\end{array}$ & $\begin{array}{l}\text { Silencing of maize (host } \\
\text { plant) defence induction } \\
\text { via insect host. }\end{array}$ & [19] \\
\hline $\begin{array}{l}\text { Regiella insecticola } \\
\text { (Facultative } \\
\text { commensal) }\end{array}$ & $\begin{array}{c}\text { Myzus persicae } \\
\text { (peach-potato } \\
\text { aphid) }\end{array}$ & $\begin{array}{l}\text { Bacteriocytes, } \\
\text { Haemolymph }\end{array}$ & $\begin{array}{l}\text { Inheritable and } \\
\text { transmitted via } \\
\text { Transovarial }\end{array}$ & $\begin{array}{l}\text { Protection against } \\
\text { parasitoids. }\end{array}$ & [20] \\
\hline $\begin{array}{l}\text { Wolbachia sp. } \\
\text { (Facultative } \\
\text { parasite) }\end{array}$ & Cimex lectularius & $\begin{array}{l}\text { Bacteriocytes, } \\
\text { extracellularly } \\
\text { scattered }\end{array}$ & $\begin{array}{c}\text { Inheritable and } \\
\text { transmitted via } \\
\text { Transovarial }\end{array}$ & $\begin{array}{l}\text { Provisioning of B } \\
\text { vitamins. }\end{array}$ & [21] \\
\hline $\begin{array}{l}\text { Candidatus } \\
\text { liberibacter } \\
\text { Psyllaurous } \\
\text { (Facultative) }\end{array}$ & $\begin{array}{l}\text { Bactericera cockerelli } \\
\text { (Tomato psyllid) }\end{array}$ & Extracellular & $\begin{array}{l}\text { Acquired during } \\
\text { feeding and vectored } \\
\text { by the insect host }\end{array}$ & $\begin{array}{l}\text { Reduced expression of } \\
\text { plant defensive gene in } \\
\text { tomato probably for } \\
\text { psyllid success. }\end{array}$ & {$[22,23]$} \\
\hline $\begin{array}{l}\text { Wolbachia sp. } \\
\text { (Facultative } \\
\text { parasite) }\end{array}$ & $\begin{array}{l}\text { Phyllonorycter } \\
\text { blancardella (Leaf } \\
\text { mining moth) }\end{array}$ & $\begin{array}{l}\text { Bacteriocytes, } \\
\text { extracellularly } \\
\text { scattered }\end{array}$ & $\begin{array}{l}\text { Inheritable and } \\
\text { transmitted via } \\
\text { Transovarial }\end{array}$ & $\begin{array}{l}\text { To increase host insect } \\
\text { fitness, the maintenance of } \\
\text { chlorophyll and } \\
\text { nutrient-rich "green } \\
\text { island" (insect feeding } \\
\text { site) in senescent leaves of } \\
\text { the host plant. }\end{array}$ & [24] \\
\hline
\end{tabular}


Table 1. Cont.

\begin{tabular}{|c|c|c|c|c|c|}
\hline $\begin{array}{c}\text { Bacterial } \\
\text { Symbionts }\end{array}$ & Insect Host & $\begin{array}{l}\text { Niche Location } \\
\text { within Host }\end{array}$ & Transmission Mode & Interaction Benefits & References \\
\hline $\begin{array}{l}\text { Buchnera spp. } \\
\text { (Obligate } \\
\text { mutualists) }\end{array}$ & $\begin{array}{l}\text { Bemisia tabaci } \\
\text { (Whitefly) }\end{array}$ & Mycetocytes & $\begin{array}{l}\text { Inheritable and } \\
\text { transmitted via } \\
\text { Transovarial }\end{array}$ & $\begin{array}{l}\text { Produces GroEL } \\
\text { chaperone protein that } \\
\text { binds to plant viruses and } \\
\text { makes virus transmission } \\
\text { efficient. }\end{array}$ & [25] \\
\hline $\begin{array}{l}\text { Hamiltonella } \\
\text { (Facultative } \\
\text { Commensal) }\end{array}$ & $\begin{array}{l}\text { Bemisia tabaci } \\
\text { (Whitefly) }\end{array}$ & $\begin{array}{l}\text { Sheath Cells, } \\
\text { Secondary } \\
\text { Myocetocytes, } \\
\text { Haemolymph }\end{array}$ & $\begin{array}{l}\text { Acquired and } \\
\text { Inheritable; } \\
\text { Horizontal and } \\
\text { Maternal }\end{array}$ & $\begin{array}{l}\text { GroEL protein produced } \\
\text { by Hamiltonella facilitates } \\
\text { transmission of tomato } \\
\text { yellow leaf curl virus } \\
\text { vectored by whitefly. }\end{array}$ & [26] \\
\hline $\begin{array}{l}\text { Candidatus } \\
\text { Westeberhardia } \\
\text { cardiocondylae }\end{array}$ & $\begin{array}{l}\text { Cardiocondyla } \\
\text { obscurior (Invasive } \\
\text { ant) }\end{array}$ & $\begin{array}{l}\text { Gut-associated } \\
\text { bacteriomes }\end{array}$ & $\begin{array}{l}\text { Transmitted to } \\
\text { late-stage oocytes; } \\
\text { Vertical transmission }\end{array}$ & $\begin{array}{l}\text { Contributes to cuticle } \\
\text { formation and is } \\
\text { responsible for host } \\
\text { invasive success. }\end{array}$ & [27] \\
\hline $\begin{array}{l}\text { Hamiltonella } \\
\text { (Facultative } \\
\text { Commensal) }\end{array}$ & $\begin{array}{c}\text { Acyrthosiphon } \\
\text { pisum (Pea aphid) }\end{array}$ & $\begin{array}{l}\text { Sheath Cells, } \\
\text { Secondary } \\
\text { Myocetocytes, } \\
\text { Haemolymph }\end{array}$ & $\begin{array}{l}\text { Acquired and } \\
\text { Inheritable; } \\
\text { Horizontal and } \\
\text { Maternal }\end{array}$ & $\begin{array}{l}\text { It confers resistance to } \\
\text { host insects from a } \\
\text { parasitoid attack. }\end{array}$ & [28] \\
\hline $\begin{array}{l}\text { Regiella insecti- } \\
\text { cola(Facultative } \\
\text { commensal) }\end{array}$ & $\begin{array}{l}\text { Acyrthosiphon } \\
\text { pisum }\end{array}$ & $\begin{array}{l}\text { Bacteriocytes, } \\
\text { Haemolymph }\end{array}$ & $\begin{array}{c}\text { Inheritable and } \\
\text { transmitted via } \\
\text { Transovarial }\end{array}$ & $\begin{array}{l}\text { Resistance to host insect } \\
\text { from fungal pathogens }\end{array}$ & [29] \\
\hline Burkholderia sp. & Riptortus pedestris & $\begin{array}{l}\text { Crypts at posterior } \\
\text { midgut } \\
\text { region }\end{array}$ & $\begin{array}{l}\text { Acquired from } \\
\text { environment and } \\
\text { undergo horizontal } \\
\text { transmission }\end{array}$ & $\begin{array}{l}\text { Symbiont-mediated } \\
\text { fenitrothion (insecticide) } \\
\text { resistance to insect host }\end{array}$ & [30] \\
\hline $\begin{array}{l}\text { Baumannia } \\
\text { cicadellinicola } \\
\text { (obligate } \\
\text { mutualist) }\end{array}$ & Sharpshooters & Bacteriocytes & $\begin{array}{l}\text { Inheritable and } \\
\text { transmitted via } \\
\text { Transovarial }\end{array}$ & $\begin{array}{l}\text { Baumannia contributes } \\
\text { several B vitamins to its } \\
\text { host insect. }\end{array}$ & [31] \\
\hline $\begin{array}{l}\text { Buchnera spp. } \\
\text { (Obligate } \\
\text { mutualists) }\end{array}$ & $\begin{array}{l}\text { Acyrthosiphon } \\
\text { pisum }\end{array}$ & Bacteriocytes & $\begin{array}{c}\text { Inheritable and } \\
\text { transmitted via } \\
\text { Transovarial }\end{array}$ & $\begin{array}{c}\text { Buchnera contributes } \\
\text { several B vitamins to its } \\
\text { host insect. }\end{array}$ & {$[32]$} \\
\hline $\begin{array}{l}\text { Wigglesworthia } \\
\text { glossini- } \\
\text { dia(Obligate } \\
\text { mutualist) }\end{array}$ & Tsetse flies & Bacteriocytes & $\begin{array}{l}\text { Inheritable and } \\
\text { transmitted via } \\
\text { Transovarial }\end{array}$ & $\begin{array}{l}\text { Wigglesworthia presence } \\
\text { during the development } \\
\text { of larval stages is vital for } \\
\text { Tsetse flies' immune } \\
\text { system development and } \\
\text { function. }\end{array}$ & [33] \\
\hline $\begin{array}{l}\text { Sodalis glossinidius } \\
\text { (Secondary } \\
\text { facultative) }\end{array}$ & Tsetse flies & Numerous tissues & $\begin{array}{l}\text { Both inheritable and } \\
\text { acquired; } \\
\text { Transmitted via milk } \\
\text { gland, mating and } \\
\text { transovarial }\end{array}$ & $\begin{array}{l}\text { Sodalis impacts tsetse flies } \\
\text { vector competence and } \\
\text { longevity }\end{array}$ & [34] \\
\hline $\begin{array}{l}\text { Serratia symbiotica } \\
\text { (Facultative } \\
\text { symbiont) }\end{array}$ & Aphids & NA & $\begin{array}{l}\text { Acquired from the } \\
\text { environment; } \\
\text { Horizontal } \\
\text { transmission }\end{array}$ & $\begin{array}{l}\text { In the Lachninae subfamily, } \\
\text { Serratia supplements } \\
\text { Buchnera aphidicola ability } \\
\text { of tryptophan } \\
\text { biosynthesis. In } \\
\text { Acyrthosiphon pisum, S. } \\
\text { symbiotica is involved in } \\
\text { heat stress tolerance and } \\
\text { parasitoid resistance to } \\
\text { host insect. }\end{array}$ & [35] \\
\hline
\end{tabular}


Table 1. Cont.

\begin{tabular}{|c|c|c|c|c|c|}
\hline $\begin{array}{c}\text { Bacterial } \\
\text { Symbionts }\end{array}$ & Insect Host & $\begin{array}{l}\text { Niche Location } \\
\text { within Host }\end{array}$ & Transmission Mode & Interaction Benefits & References \\
\hline $\begin{array}{l}\text { Serratia marcescens } \\
\text { (Facultative } \\
\text { symbiont) }\end{array}$ & $\begin{array}{l}\text { hematophagous } \\
\text { insects }\end{array}$ & midgut & $\begin{array}{l}\text { Adhere to eggs } \\
\text { surface, colonize } \\
\text { oviposition site }\end{array}$ & $\begin{array}{c}\text { Serratia marcescens have an } \\
\text { anti-Plasmodium function } \\
\text { in Anopheles mosquito } \\
\text { midgut }\end{array}$ & [36] \\
\hline Fungal Symbionts & Insect Host & $\begin{array}{l}\text { Niche location } \\
\text { within the host }\end{array}$ & Transmission mode & Interaction Benefits & References \\
\hline \multirow{3}{*}{$\begin{array}{l}\text { Grosmannia } \\
\text { clavigera } \\
\text { (Obligate } \\
\text { mutualist) }\end{array}$} & \multirow{3}{*}{$\begin{array}{l}\text { Dendroctonus } \\
\text { ponderosae (Bark } \\
\text { beetle) }\end{array}$} & \multirow{3}{*}{$\begin{array}{l}\text { Mycangia, } \\
\text { exoskeleton }\end{array}$} & \multirow{3}{*}{$\begin{array}{l}\text { Acquire spores in the } \\
\text { pupal chamber just } \\
\text { before emergence }\end{array}$} & $\begin{array}{l}\text { Increased success of host } \\
\text { insect on jack pines (host } \\
\text { plant) reduces food } \\
\text { quality for interspecific } \\
\text { competitors }\end{array}$ & [37] \\
\hline & & & & $\begin{array}{c}\text { Oxygenated } \\
\text { monoterpenes produced } \\
\text { by microbial activity is } \\
\text { used as host (beetle) } \\
\text { location cues by } \\
\text { parasitoids. }\end{array}$ & [38] \\
\hline & & & & $\begin{array}{l}\text { Grosmannia clavigera can } \\
\text { detoxify oleoresin } \\
\text { terpenoids } \\
\text { (conifer-defence } \\
\text { chemicals) and utilize } \\
\text { them as carbon sources. It } \\
\text { allows host insects to } \\
\text { tolerate terpenoids and } \\
\text { grow successfully on pine } \\
\text { hosts }\end{array}$ & [39] \\
\hline $\begin{array}{l}\text { Raffaelea lauricola } \\
\text { (obligate } \\
\text { mutualist) }\end{array}$ & $\begin{array}{c}\text { Xyleborus glabratus } \\
\text { (Redbay ambrosia } \\
\text { beetle) }\end{array}$ & $\begin{array}{l}\text { Mycangia, } \\
\text { exoskeleton }\end{array}$ & $\begin{array}{l}\text { Larvae and adults } \\
\text { feed on the conidia }\end{array}$ & $\begin{array}{l}\text { Volatile cues from fungal } \\
\text { symbionts may function } \\
\text { as a mechanism to locate } \\
\text { established fungal gardens } \\
\text { of conspecific beetles } \\
\text { (suitable microhabitat) but } \\
\text { also as an orientation cue } \\
\text { within a gallery }\end{array}$ & [40] \\
\hline
\end{tabular}

\section{A Glimpse of Insect-Microbe Niche Foundations}

\subsection{Morphology and Physiochemical Conditions of Niches}

Symbionts (i.e., viruses or archaea, bacteria, protist, and fungi) direct the insect's growth and development trajectory. The basic niche foundation is established in conjuncture by both insects and symbionts [41,42]. This co-constructed niche is pivotal in insect diversification and is responsible for their eco-evolutionary success [43]. Besides multiple habitat options inside insects, the cuticles and gut are most accessible to microbial colonists. The ability of microbes to breach the exoskeleton and gut wall provides them access to hemocoel and insect cells [13]. Cuticles, a crucial physical barrier, can host more than thousands of bacterial cells. Cuticular invaginations (such as mycangia) and glandular invagination (like crypts or foveae) act as culture vessels; they protect microorganisms from abiotic factors and contamination [44,45]. However, some physical and chemical disturbances like ecdysis, antimicrobial secretions, and grooming behaviours limit microbial growth [46].

The attributes of the insect gut, such as the availability of nutrients and protection from desiccation and UV, make the gut favourable for colonisation. However, it also poses 
multiple challenges for microbes, such as (a) an unfavourable oxygen content, redox potential, and $\mathrm{pH}$ in the gut lumen; (b) digestive enzymes secretion; (c) physical disturbances like peristalsis; (d) secretions of the immune system; (e) habitat loss during insect moulting; and (f) competition among microbes for resources and colonisation sites. The hazard and resource accessibilities vary within the gut compartments with the insect stages and across insect groups based on their feeding ecology $[10,47]$. In most insects, the hindgut bears a more significant proportion of the microbial population. For example, in termites and scarab beetles, the hindgut acts as an anoxic fermentation chamber in which microbes degrade complex plant materials. In Cortaritermes, an integrative omics approach characterised carbohydrate-active enzymes from Fibrobacteres and Spirochaetae. They are present in the termite gut to overcome lignocellulose recalcitrance of the Miscanthus diet [48]. The spectra of the termite-fungal community were found stable across diverse host species from different habitats [49].

In comparison, an analysis of bacterial communities in termite guts and galleries demonstrated a unique pattern [50]. With the flux of digestive enzymes and immunologically active compounds, the midgut is hostile to microorganisms. Most insects have mild acidic to neutral $\mathrm{pH}$ ( $\mathrm{pH}$ 6-7) in the midgut, favouring diverse microorganisms' growth. However, some insect guts like lepidopteran have alkaline midguts ( $\mathrm{pH} 8-12)$, inimical for microbial growth. Besides chemical barriers, the peritrophic matrix (PM) poses a physical barrier to microbial colonisation [13]. The majority of microorganisms fails to penetrate the PM and pass passively along with food [51,52]. Some bacterial communities reside in ectoperitrophic spaces. In some insects, the crop (food storage organ) is the primary habitat for microorganisms. However, regular food evacuation makes it a provisional habitat. In insect vectors, the foregut is the site of microbial adhesion for plant or animal pathogens.

Furthermore, certain insect groups have specialised cells, i.e., bacteriocytes (for bacteria) and mycetocytes (for yeast) for maintaining and hosting microorganisms. Microbes are restricted to these cells, with no access to the external environment, and are vertically transmitted [53]. The insects belonging to different feeding guilds with divergent evolutionary trajectories also shaped their microbial partners during evolution. Lepidopteran larvae feed on foliage and have simple gut morphologies that support a simple gut microbiome [54], including genera Pseudomonas, Enterobacter, Enterococcus, and Klebsiella, along with a few fungi. In contrast, the coleopteran gut is highly segmented, with certain modifications and enlargements based on their diet. They show marked variations in gut microbial communities $[55,56]$. In comparison to holometabolous insects, hemipterans gut tissues and microbiomes show significant modifications. The sap feeders lack PM and consume an extreme diet, harbouring symbionts primarily for nutrient provisioning [53].

\subsection{Impact of Host Immune System on Resident Symbionts}

Besides various factors (like the host diet, $\mathrm{pH}$, pathogenic invasion, and ecological niche of the host) that affect the gut microbiome composition, there is firm evidence indicating the influence of the insect gut immunity in shaping the resident microbial community structure. Recently, an ant microbiome association suggested the importance of social interactions in shaping the host-microbiome [57]. Additionally, the composition of the microbiome varies across distinct nest chambers [58]. The painstaking efforts of insects to resist and eliminate foreign pathogens or opportunistic microbes while spurring beneficial microbes are crucial to insect survival and eco-evolutionary success (Figure 1). This perplexing immune response in the alimentary canal to eliminate invasive pathogens and simultaneously encourage or tolerate commensal microorganisms ensures homeostasis in the gut. For maintaining microbial homeostasis, different immune regulatory mechanisms have been deciphered. This includes (a) the immune deficiency (Imd) pathway, (b) dual oxidase-reactive oxygen species (Duox-ROS), (c) Janus kinase signal transducer, and (d) JAK/STAT pathway (activators of signal transduction) [59]. 


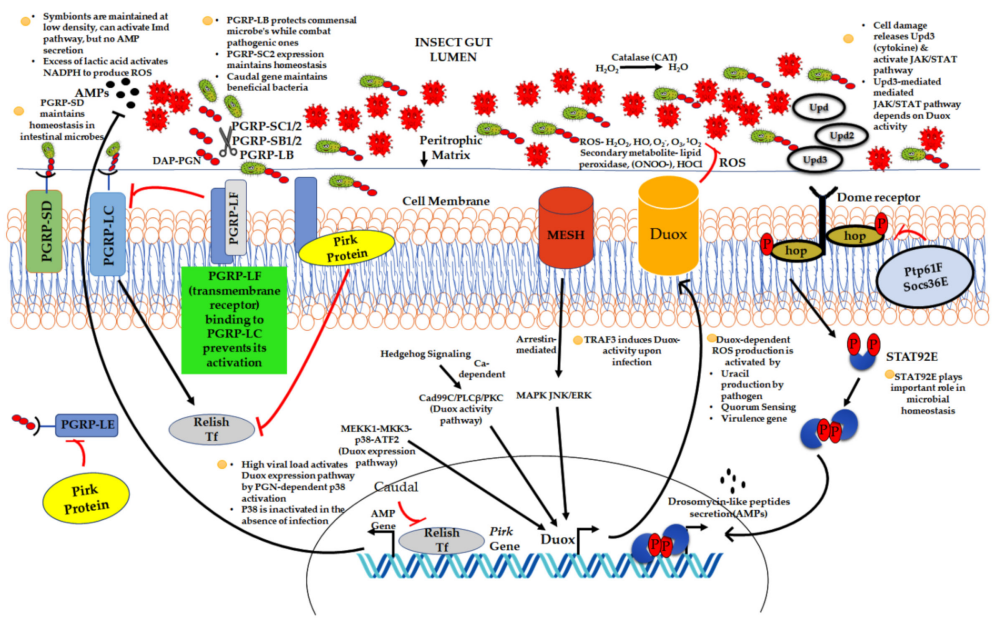

Figure 1. Depictions of different mechanisms involved in the maintenance of microbial homeostasis in the insect gut. The microbial homeostasis is attained by AMPs and reactive oxygen species (ROS) production. The Imd pathway is activated during high viral loads by recognising bacteria-derived peptidoglycan by the cell surface protein (PGRP-LC) and cytoplasmic receptor (PGRP-LE). PGRPSD enhances Imd pathway signalling. AMPs are produced by the Imd pathway in the gut. Texts written in red are the negative regulators of the Imd pathway. Duox (member of NADPH oxidase family) produces ROS. It is mainly regulated by the Duox activity pathway and Duox expression pathway. Recently, MESH-regulated Duox activity has also been reported. Besides Imd pathwaymediated AMP production, the JAK/STAT pathway also produces a few AMPs. The combining of Upd molecules (cytokines) to the Dome receptor activates JAK/STAT signalling. Ptp61F and Socs $36 \mathrm{E}$ are the negative regulators of the JAK/STAT pathway. The text written in green describes the regulatory aspect of different mechanisms in microbial homeostasis. DAP PGN-Diaminopimelic acid (DAP)-type peptidoglycan (PGN), PGRP_PGN recognition peptide, AMPs—antimicrobial peptides, Dome — domeless, Hop—hopscotch, Upd—unpaired, and TRAF3-Tumour necrosis factor receptor (TNFR)-associated factor 3. Pathogen- Beneficial or commensal bacteria

\section{Microbial Symbiont: A Stealthy Modulator of Insect-Plant Interactions}

The ramification of insect-microbes symbiosis is considerably subtler in insect-plant interactions [60]. Insect mutualists allow insects to colonise diverse plant species by actively manipulating host plant physiology and enhancing the antiherbivore defence in their favour [61]. However, the extent to which symbionts incline the balance favouring host insects is still ambiguous and needs further experimentation. The role of microbial symbionts, "the hidden players", is currently underappreciated. The herbivorous insects acquire gut microbial communities from their respective host plants. Hence, they vary with the host plant range [62]. Plant-derived allelochemicals often shape the gut microbiome by stimulating or inhibiting the growth of their respective microbial communities $[63,64]$. The microbial community structure also depends on the insect gut environment, microbial source, and plant genotype [65]. The gut microbiome plays a critical role in influencing the plant defence efficacy on phytophagous insects (Figure 2). The microbial symbiont (a) alters the efficacy of plant toxins targeting the insect gut peritrophic matrix (b) metabolises/detoxifies/degrades plant defensive secondary metabolites, and (c) modulates the induction of plant defence signalling $[47,66,67]$. 


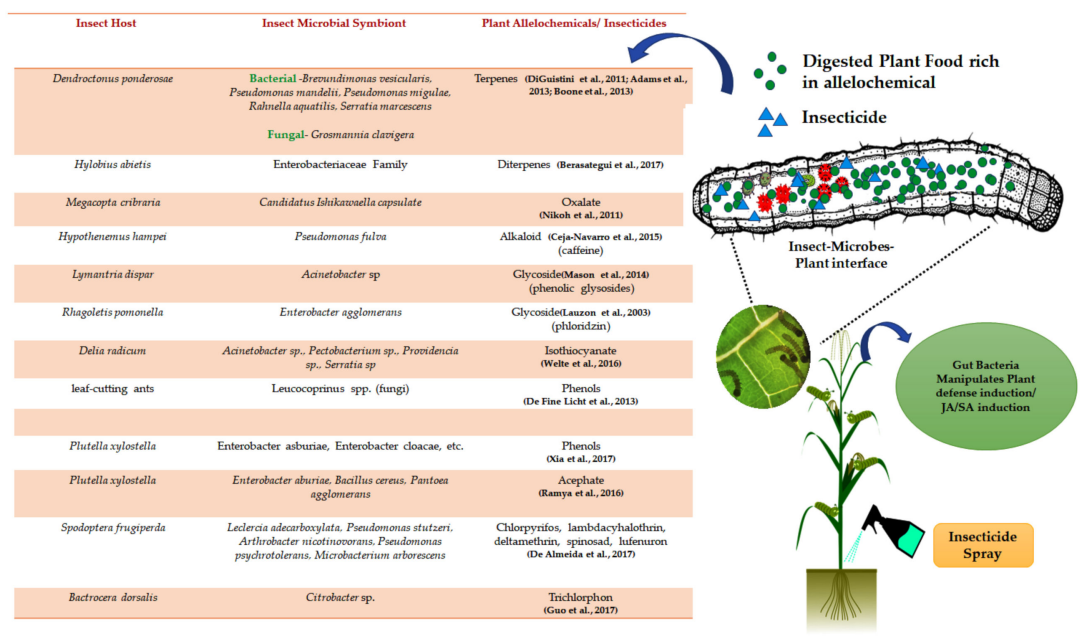

Figure 2. Pictorial representation of the insect-microbes-plant interface inside the gut of phytophagous insects. Insect-associated microbes manipulate host plant defence induction and metabolise/detoxify phytotoxins. Insect mutualists also detoxify insecticides and enhance the host fitness.

The peritrophic matrix, a protective barrier of coleopteran and lepidopteran guts, is one of the critical targets of plant defensins (chitinase and protease). The disruption of the integrity of the PM by plant hydrolytic enzymes also co-opt resident gut bacteria for synergising their total activity [68]. It has been well-documented that some of the gut symbionts can effectively metabolise plant-derived toxic chemicals (phenols, terpenoids, alkaloid (caffeine), and glycoside) and render them inoperable [69-71]. The coevolutionary adaptation of Acromyrmex echinatior. (leaf-cutting ant) with Leucocoprinus gongylophorus (fungal symbiont) allowed the selection of the laccase enzyme in the fungal cultivar. It imparted a fitness advantage to ants by successfully detoxifying phenolic compounds using laccase and alleviating dietary challenges [72]. The isolation of gut microbial strains from Delia radicum (Cabbage root fly) identified the plasmid-carrying saxA gene among some isolated strains. The product of the saxA gene could degrade isothiocyanate, an insecticidal toxin of cabbage [73].

Similarly, metagenomics of the Plutella xylostella gut microbiota provided insight into the enrichment of genes involved in digestion, amino acid synthesis, and the detoxification of plant phenolics [74]. Finally, identifying core bacterial and fungal populations in the gut of bark beetles feeding on conifers paved the way for the improved knowledge of insect adaptation to conifer feeding as a holobiont $[75,76]$. The fungal symbiont, Ceratocystis polonica of bark beetles (Ips typographus), could effectively metabolise Stilbene, an antifungal compound in Norway spruce. It benefits bark beetles [77]. Recently, studies have been performed to comprehend the role of a microbial symbiont in metabolising insecticides (Figure 2). The promising role of gut bacteria-driven insecticide detoxification/degradation has been found $[78,79]$. For example, the gut-associated bacterial community of Plutella xylostella (a crucial pest of cruciferous) contains Enterobacter aburiae, Bacillus cereus, and Pantoea agglomerans, which aid in Acephate degradation [80]. Likewise, exploring the Spodoptera frugiperda gut microbial community documented an excellent reservoir for insecticide-degrading bacteria [81].

Besides degrading plant secondary metabolites, insect mutualists could modulate induced plant defences by quenching the free radical activity, utilising JA/SA antagonism, favouring the insect host and suppressing the expression of the plant defensive gene [82-85] (Figure 2). The evidence supports the interference in the insect-induced plastic phenotypic response in plants by microbial mutualists $[19,23]$. However, the impact of insect mutualists on the host fitness is obscure. The symbiotic partner might contribute a new genetic resource that gives its host the ability to synthesise bioactive molecules. For example, a crucial and well-studied elicitor (N-acylamino acids) of plant defences, widespread in 
the oral secretion of chewing insects, has been discovered to be synthesised in vitro by the gut symbiotic bacteria of noctuid caterpillars [86]. Another example from leaf miners involves the maintenance of the "green island" (photosynthetically active green area in senescent leaves) in host plant leaves. The leaf-mining moths (Phyllonorycter blancardella) harbour Wolbachia (a bacterial symbiont), which produces cytokinins, responsible for green island formation. The removal of Wolbachia leads to the disappearance of the green island and increased moth mortality [24]. Still, our understanding of the role of microbes as a mediator in insect-plant interactions is nascent. It requires comparative studies between related herbivore insects varying in diet breadths and manipulation of the gut microbial community. It is worth mentioning here that the manipulation of symbiotic association is challenging in many insect orders.

\section{Microbiome Sabotaging the Vector Competence of Insect Hosts}

Several human pathogens are circulated in the population by insect vectors, particularly mosquitoes. This has impacted human health globally. Intriguingly, most of these disease carriers have an innate resistance to the vectored pathogen. Different studies have demonstrated that only a tiny section of insect vectors has a thriving infection to transmit to healthy hosts successfully. However, most insects eliminate pathogens in the midgut soon after a bloodmeal, based on vector competence. Vector competence is the genetic ability of pathogen transmission by host insects. It is based on insects' immune system proficiency that governs multiple immunity pathways $[15,87]$. To understand insect responses to pathogen infections, high-throughput gene profiling and reverse genetic analysis, i.e., the RNA interference (RNAi) approach, was used, which recorded the induction of a large set of innate immunity genes [88]. Furthermore, the rearing of insect vectors such as Aedes aegypti aseptically recorded a higher fold of pathogen infection compared to the wild-type. Such observations implicated the role of microbial fauna in modulating the immune resistance and vector competence of the host insect [89].

Here, we reviewed the influence of insect symbiotic microbiota on arboviral transmission and the intricacy of interactions modulating the vectorial capacity of arthropods, particularly vector competence. The core component of vector competence that we have highlighted is the proficiency of the host insect immune system and its responses to microbial challenges-how the microbial fauna of a vector modulates the transmission of arboviruses. The mechanisms underpinning the inherent symbiotic microbiota in arthropods to reduce arboviral transmission and pathogen blocking could be harnessed as a potential disease control of arthropod-borne diseases.

\subsection{Arthropod Vector and its Symbiotic Microbiota}

Bacterial symbionts found in mosquitoes, sandflies, and ticks dominantly belong to Actinobacteria, Bacteroidetes, Firmicutes, and Proteobacteria [90-93]. They live in the gut and hemocoel. Symbionts have been reported from insects relying on a nutritionally deficient diet like vertebrate blood, plant phloem, and wood. Such symbiotic associations fulfil their nutrient needs in their diet. They offer mutualistic symbiosis and are known as primary symbionts. The quality of being indispensable for their hosts made them evolve to be vertically transmitted within their hosts. This ancient relationship shares a long coevolutionary history. It has made drastic changes in primary symbionts, such as reducing the genome size, gene loss, and selecting essential genes and pathways that favour unique niches in their host. For instance, Buchnera aphidicola, Wigglesworthia, and Blochmannia [94] are some of the more well-studied symbionts. B. aphidicola is an obligate endosymbiont of aphids. It lives distinctively inside host cells, i.e., bacteriocytes, and has customized its genes to provide aphids with essential nutrients and proteins deficient in their diet [32]. Likewise, Wigglesworthia is also an obligatory endosymbiont that resides in the bacteriome organ of tsetse flies. It is essential for their immune system development [33,95]. Another category of transient symbionts and originating recently in insects is commensal microbes known as secondary symbionts. Compared to the primary symbiont, secondary symbionts 
are dispensable, and their transfer from mother to progeny shows a lower fidelity. They can be transferred through different means, such as vertical, horizontal, or acquired from the environment-for example, Hamiltonella defensa from sap feeders and Sodalis glossinidius from tsetse flies. Hamiltonella defensa is a sporadic endosymbiont of sap-feeding insects that prevents the attack of parasitic wasps and protects them [96]. Sodalis glossinidius, an intracellular symbiont of the tsetse fly, lives in different tissues, including the gut lumen [97]. Besides mutualistic and commensal microbes, most insects also carry parasitic microbes maternally transferred; Wolbachia is extensively explored. Wolbachia is an intracellular Gram-negative bacterium that infects many arthropod insect species in nature. Until recently, its infection was considered parasitic, because it leads to several reproductive abnormalities in its host. Some Wolbachia strains can reproductively modify their hosts. One type of modification, called cytoplasmic incompatibility (CI), occurs when Wolbachiainfected males mate with uninfected females or females infected with an incompatible strain of Wolbachia, resulting in early embryonic death of their offspring. Moreover, multiple Wolbachia strains have been shown to confer resistance to viral infections in their native hosts. For example, many native Wolbachia infections in D. melanogaster (wMel, wMelCS, and wMelPop) and D. simulans (wAu and wRi) have been shown to provide viral protection to their hosts [98-106]. Additionally, the Wolbachia strain wPip has also been shown to increase the resistance to West Nile virus in its native mosquito host, Culex quinquefasciatus. Considering the capabilities of Wolbachia, it provides a promising tool for controlling disease vectors, thereby reducing virus transmission. Recent studies have shown that, when Aedes aegypti mosquitoes are transinfected with various Wolbachia strains, both CI and the resistance to viral infection are also conferred to their novel host. A. aegypti mosquitoes infected with the wMel and wAlbB strains of Wolbachia have been released in field trials in different countries such as Australia, Malaysia, and Indonesia as a strategy for controlling dengue [107-111]. New mosquito lines infected with other Wolbachia strains such as wMelCS, wRi, and wPip are currently under investigation for their effectiveness in disease control and as candidates for release in field trials [111].

Symbionts remain in harmony inside the arthropod vector. They establish homeostasis in host tissues by utilising either their molecules or different host-derived factors. Symbiotic microbes use various strategies and mechanisms to prevent the activation of the hostile immune system of the hosts. Whereas hosts also adjust their immune responses to support beneficial symbiosis and keep a check on symbiont growth. The gut is the crucial site for pathogen entry, and its condition decides the fate of the pathogen, i.e., its colonisation and survival. The cells of the host epithelium release a constitutive rush of antimicrobial peptides (AMPs) via activation of the immune deficiency (Imd) pathway and a high level of reactive oxygen species (ROS) to manage microbial outgrowth in the gut [112]. However, multiple negative regulatory elements of the Imd pathways have been reported to avoid damaging effects on native gut microbes. In Drosophila, pathogen recognition proteins (PGRPs), PGRP-LB, and PGRP-SC could scavenge peptidoglycan (immunostimulatory) and enable host tolerance to commensal microbes in the gut. Another regulator of the Imd pathway PGRP-LC-interacting inhibitor of Imd signalling (PIMS) could translocate the PGRP-LC receptor (activator of the Imd pathway) from the cell membrane to the intracellular compartment. The translocation of PGRP-LC from the plasma membrane inhibits Imd signalling to commensal bacteria [113]. The mosquito gut microbiome modulates the expression of C-type lectins (mosGCTLs) and coats bacterial surface ligands (polysaccharides) with mosGCTLs. It not only evades interactions between AMPs and the bacterial surface, but it also hides bacterial ligands from the pattern recognition receptors (PRRs) present in the gut epithelium [114]. The dual oxidase (DUOX)-dependent ROS production, a bona fide defence mechanism, was demonstrated in Drosophila gut epithelia for the controlled maintenance of a nutritional microbe: yeast [115].

The effective expression and regulation of ROS synthesising the Duox enzyme maintain the homeostatic condition and a healthy gut-microbiota interaction. In Aedes aegypti and phlebotomine sandflies, ROS was found to maintain the composition and homeostasis 
in the gut microbiome. However, limiting ROS production resulted in dysbiosis in Aedes aegypti $[116,117]$. The transinfected Wolbachia strain, wAlbB, demonstrated an increased ROS level followed by the upregulation of different antioxidant genes in A. aegypti. The antioxidant-mediated regulatory feedback prevents cell damage and maintains a persistent Wolbachia infection [118]. On the contrary, a Wolbachia natural infection neither upregulates nor suppresses the AMP-mediated immune response in insect hosts $[119,120]$. Such an observation could plausibly be because, being located within vesicles, Wolbachia hides from the host immune system and, therefore, does not induce AMP gene expression, or the host favours the maintenance of the bacteria by shutting down the AMP immune response [121].

Besides immune system modulation, bounding a physical barrier around microbes in vectors also limits the microbial fauna and contributes to homeostasis by evading the adverse host effects. An immunomodulatory peroxidase (IMPer)/Duox system uncovered in the Anopheles gambiae midgut epithelium forms a dynamic and transient di-tyrosine network upon blood feeding. This protein network decreases the flow of immune elicitors and its interaction to PRR present on the midgut cell membrane. It promotes commensal bacteria proliferation and protects the gut microbiota; instead, it makes $A$. gambiae susceptible to Plasmodium infection [122]. Wolbachia infection corroborates the above described by being restricted to cytoplasmic vesicles near the cell membrane [123]. The membrane of these vesicles is derived from the host that allows Wolbachia to hide from the host immune system. In new infestations, it triggers immune activation, whereas coevolved symbiosis involves stealthy growth inside the host via the suppression and interference of host immune responses. It requires the maintenance of redox homeostasis by balancing redox activation with the induced expression of antioxidants [124]. Therefore, conclusively, both microbial fauna and arthropod hosts tune up at the microbe-host interface for effective symbiosis.

\subsection{Insect as a Carrier of Plant and Mammalian Pathogens}

Besides beneficial microbes, insects also shelter microbes pathogenic to mammals or plants. They encompass over 130 arboviruses that cover the Flaviviridae, Reoviridae, Togaviridae, Orthomyxoviridae, and Bunyaviridae families. Insect-vectored viruses pose serious public health issues to humans, such as the Chikungunya virus, Dengue virus, West Nile virus, Japanese encephalitis, Yellow fever, and Zika virus. Insects acquire such pathogens while feeding on infected hosts and transmit to healthy hosts in subsequent feedings. These prolific insect vectors crave vertebrate blood to support egg development [125]. These vectors have expanded their geographic range due to global transport, mushrooming urbanisation, and climate change. As we lack efficacious vaccines against vector-borne pathogens, insecticides are a mainstay. However, insecticide-based vector control is in jeopardy due to the emergence of the resistance in the natural population [126]. It diverted substantial effort to procuring genetic information, parallelly unravelling insect biology and its interactions with pathogens. Its prime focus is gathering evidence on different aspects of vector physiology and vector competence (an insect's ability to transfer pathogens) to stop transmissions, an effective alternative to massive insecticide usage [127]. It uncovers an unprecedented research area involving tripartite interactions among arthropod vectors-symbionts-arboviruses.

\subsection{Tripartite Interaction of Symbionts-Arthropod-Borne Pathogens-Insect Vectors}

The investigation of endosymbionts that featured their role in thwarting host vector competence is prime. Indeed, microbiota determined the vector susceptibility to arboviruses by modulating immune responses. The antibiotic treatment seemed more beneficial for DENV infections in mosquitoes than mock-treated mosquitoes [89]. In both Anopheles stephensi and A. albimanus, a Plasmodium vector, mosquitoes reared aseptically showed enhanced susceptibility to Plasmodium infection. Again, though, the susceptibility to pathogen infections was lowered compared to the normal by mere cofeeding Plasmodium and mosquitoes' bacteria. The large-scale gene profiling of mosquitoes reared in septic and aseptic conditions featured a significant induction of immune genes and anti-Plasmodium 
factors, possibly by the microbes of the host. The gut microbes are now known to induce a basal level of the host's antiviral immunity [128-130]. Similarly, depriving tsetse flies of Wigglesworthia (an obligate, commensal microbe of a tsetse fly) made flies highly susceptible to Trypanosoma infection [131].

Based on the interaction of microbes with vector-borne parasites, the microbiota can impact the vector competence of insect hosts by both direct and indirect means. Under the direct means, microbes hold a direct influence on the parasite through some metabolite secretions. For example, Chromobacterium secrets an aminopeptidase that directly degrades the envelope protein of DENV [132]. In A. aegypti caught from the field, Serratia odorifera, a commensal bacterium, was discovered to promote DENV-2 infection through some polypeptide secretion. The inoculation of $A$. aegypti with $S$. odorifera was found to increase CHIKV infection [133]. Alternatively, microbes can halt pathogen growth indirectly by modulating the host's physical status and immune system. The symbionts can induce the host immune system and antiviral mechanisms such as AMP production, ROS burst, and Imd and Toll signalling pathways. A study conducted in the mosquito population from Zambia identified Enterobacter bacterium. The Enterobacter-induced ROS showed anti-Plasmodium effects [134]. Intriguingly, gut microbes play a vital role in synthesising and maintaining the peritrophic matrix (PM), preventing pathogen invasion in insect guts after a blood meal. Dysbiosis or the loss of gut commensal bacteria severely affects the PM and, ultimately, pathogen colonisation in insect vector gut epithelium [135-138]. PGRP-LB exhibits a dual role in tsetse flies.

Conversely, it negatively modulates the Imd pathway and protects Wigglesworthia (a mutualistic symbiont). On the other hand, a higher expression of PGRP-LB curtails the establishment of Trypanosoma. The microbial fauna seems to prime the host immune system and enhance the immune response to subsequent parasite challenges. Wigglesworthia does not directly influence the tsetse fly immunity to Trypanosoma, although its presence during the immature larval stages in adult flies marks the proper development and function of the immune system in developing larvae $[33,139]$. Correspondingly, an intimate association was found between beneficial gut microbes and haemocytes. In A. gambiae, an invasion by Plasmodium in the midgut increases the abundance of granulocytes in the insect hemocoel and enhances the immunity to bacteria while reducing viral reinfection [140]. Similar manifestations of immune priming of the host were observed in some Wolbachia infections. wMelPop Wolbachia trans-infection in A. aegypti was shown to upregulate immune genes, which may contribute to resistance to viral infection, although it is clear that other factors also contribute [141]. Thus, both direct and indirect means of pathogen blocking can significantly impact the vectorial capacity of the insect host.

\section{Wolbachia: A Panoply of Tactics for Vector-Borne Disease Control}

The unravelling of Wolbachia's role in interfering with viral replication in Aedes aegypti prompted inquisitiveness about the mystery of the mechanism employed by Wolbachia in virus blocking. It also pronounced Wolbachia as a potential biocontrol agent. Besides multiple Wolbachia strains, wMel and wAlbB could effectively block viral transmission [111]. The mechanism of virus blocking is enigmatic [142]. It might be achieved by several contributing factors that include (a) immune activation by the ROS-dependent Toll pathway (b) using host microRNAs and the (c) density of Wolbachia in crucial tissues, which also impact the extent of virus blocking [118,143-146]. The Wolbachia population competes with viruses for host resources (like cholesterol) and other molecules. The artificial introduction of Wolbachia strains such as wMel or wMelPop triggered cytoplasmic incompatibility in wild $A$. aegypti populations, leading to pathogen interference phenotypes by modulating the immune system and metabolic pathways. Cytoplasmic incompatibility (CI) is unrelated to pathogen interference. CI allows for Wolbachia to increase in frequency in the population. When a large proportion of mosquitoes are infected with Wolbachia, this will result in a decreased transmission of pathogenic viruses such as DENV and ZIKV $[144,147,148]$. Viruses like DENV and WNV are heavily dependent on cellular lipids, 
whereas the lipidome is perturbed upon Wolbachia infection $[148,149]$. The lipid profile of acyl-carnitines (a class of lipid) was prominently altered [150,151]. Acyl-carnitines are important intermediates involved in FA-CoA transport to the mitochondria further used for $\beta$-oxidation and ATP production. The viral infection elevates the acyl-carnitine levels in Aedes aegypti and disrupts signalling in mitochondrial functions, leading to diversions in cellular energy production [151]. In contrast, Wolbachia decreases the acyl-carnitine level and promotes FA-CoA catabolism. Wolbachia infection induces changes but does not perturb the cell homeostasis [152]. Another mechanism that Wolbachia utilises for pathogen blocking involves the downregulation of the activity of the insulin receptor kinase. The decrease of insulin receptors inhibits insulin signalling, reducing virus replication [153]. Insulin signalling is linked to acyl-carnitine. Therefore, the building up of acyl-carnitine upon viral infection could impair insulin signalling [154]. Wolbachia also modulates the homeostasis of the lipid and cholesterol to inflict pathogen blocking [155].

Recent studies showed that wMel A. aegypti mosquitoes could be successfully deployed at a large scale to control dengue in different countries like Australia [156], Indonesia [157], and Brazil [158]. Furthermore, agricultural pests such as aphids, planthoppers, and whiteflies cause severe damage to crops through feeding or by transmitting plant viruses [159-161]. A recent study suggested that the introduction of Wolbachia strain wStri into planthoppers, Nilaparvata lugens, inhibited infection and viral transmission in rice plants, thereby opening up new avenues in the development of Wolbachia-based control strategies against agricultural pests [162].

\section{The Extended Microbial Contribution in Insect-Microbiome Interaction: A Quantum Leap}

The microbiota that colonise insects contribute significantly to alleviating dietary challenges and maintaining homeostasis in the gut by facilitating host immunities. Besides, they mediate a wide array of ecologically important traits in insects and structure their functions, ecology, and evolution. For example, Candidatus Westeberhardia cardiocondylae, a gut-associated symbiont of Cardiocondyla obscurior, contributes to host cuticle formation and promotes an invasive lifestyle. Westeberhardia resides in ovarian nurse cells and is vertically transmitted [27]. In Daceton armigerum, $16 \mathrm{~S}$ rRNA and $18 \mathrm{~S}$ rRNA analyses of the microbial communities revealed different ecological and evolutionary factors shaping the host microbial communities [163]. A high-throughput sequencing technology of Temnothorax nylanderi ants identified the impacts of the environment and season on the diversity of the abdominal microbiome of ants rather than their caste [164]. Therefore, we will briefly address the microbiome's role in determining host behaviour, physiology, and evolution.

\subsection{Vitamin B Provisioning in Insect Nutrition}

Insect genomics has demonstrated insects' inability to synthesise B vitamins de novo. It also offered the insight of microbial contributions to supplement $B$ vitamins to insects feeding on a diet deficient in B vitamins (vertebrate blood and plant sap). The axenic insects show depressed performances and require a regular supply of seven B vitamins $[165,166]$. The genomics analysis of Wolbachia, a symbiont in Cimex lecticularis, revealed a complete biosynthetic pathway for synthesising B vitamins (B2 and B7) [21]. Similarly, Baumannia, a symbiont of sharpshooters (sap feeder), is genetically capable of synthesising several B vitamins [31]. In another sap-sucking insect, Acyrthosiphon pisum, similar B vitamin provisioning was observed by Buchnera, a bacteriocyte-localised bacterial symbiont [32]. The requirement of the same set of $B$ vitamins in insects as mammals and the absence of symptoms to individual B vitamin deficiencies undervalue the importance of insect models in exploring the role of B vitamins in humans. However, the immense diversity in insect nutritional ecology, microbial mutualists, and advancement in genomics and analytical techniques offer a ray of hope in vitamin B nutrition. 


\subsection{Microbial Secondary Metabolite-Driven Insect Community Interactions}

A complicated multipartite symbiosis encompasses insect communities. These community interactions are commanded by a wide array of secondary metabolite secretions by insect-associated microbes. These complex networks of interactions ultimately shape insect symbiosis. For example, the antennal gland in solitary wasps, i.e., beewolves, cultivate the bacterium Streptomyces in their antennal glands. This bacterium monoculture produces piericidin polyketide (an antifungal compound). It protects larvae and enhances their survival [167]. Another example is from entomopathogenic nematodes Steinernema and Heterorhabditis that prey on various insects using their bacterial symbionts Xenorhabdus and Photorhabdus. These nematode-associated bacterial symbionts are released in insect haemolymphs by juvenile infective nematodes. The bacteria grow inside the insect and kill it. This provides a nutrient-rich breeding ground to nematodes that feed on bacteria, and the dead insects remain until the next attack. Xenorhabdus and Photorhabdus produce various secondary metabolites to suppress insect immune responses and evade opportunistic microbes' growth on insect cadavers [168]. Similarly, fungus-growing ants (Attine ants) grow "cultivar fungus" (Leucoagaricus) for food. Escovopsis parasitise the cultivar fungus. To defend a cultivar fungus, attine ants maintain Pseudonocardia (an obligate bacterium) in the crypts of the cuticle to defend the cultivar fungus. Pseudonocardia produces antifungal secondary metabolites to inhibit Escovopsis (a parasitic fungus). A particular trait in such multipartite symbiosis experiences various sources of selection, resolved by a trade-off. Its goal is to enhance the overall fitness of symbiosis by emphasising a particular molecular interaction $[44,169]$.

\subsection{Microbiome-Shaping Insect Behaviour}

All insect groups harbour a broader microbiome in addition to endosymbionts. The key difference is in their mode of transmission. Endosymbionts are transferred via a maternal transmission with high fidelity. In comparison, the broader microbiome does not rely much on maternal transmission and is transmitted via environmental factors. Vertically transmitted symbionts inherited from mother to offspring persist as mutualists influencing the host fitness or reproductive manipulators [170]. Some of these reproductive manipulators induce cytoplasmic incompatibility or are sex ratio distorters that increase the ratio of female offspring in the infected population, thereby altering the dynamics of sexual selection $[171,172]$. The bacterial symbiont Wolbachia modulates insect reproductive behaviours via feminisation and male-killing [173]. Other symbionts such as Rickettsia and Siproplasma also influence the sex ratio in diverse arthropod hosts such as Drosophila [174], spiders [175], and mites [176]. Another reproductive behaviour manipulator, Cardinium, influences the oviposition choice of Encarsia pergandiella (parasitoid wasps). This behavioural manipulation is induced to increase infected daughters in the population [177]. The infection of the entomopathogenic fungi Cordyceps (the "Zombie fungus") causes a loss of appetite in their host, losing their coordination. The insects infected by the zombie fungus attach to foliage and later die. The fungal-spouting body develops on the dead host, bursts at maturity, and showers infected spores on the area below it [178]. Entomophthora muscae (a parasite of a housefly) induces necrophilia in uninfected males in a bizarre situation. They get more attracted to dead, infected females than uninfected ones [179]. Viral infection by IIV-6/Cr IV manipulates the mating behaviour of infected male Gryllus texensis and alters their courtship singing pattern [180]. The bacterial symbiont composition of the host is also altered upon interspecies competition. Bacterial communities buffer behavioural changes upon biological invasions [181]. Behavioural manipulation is the most exciting phenomenon in insect-microbiome interactions [12].

\subsection{Gut Microbiota Linking Insects' Nervous System, Physiology, and Behaviour}

Recently, the link between the gut microbiota and animal neurophysiology and its behaviour has gained an exponential thrust. The studies conducted on mammalian models are now extrapolated to insect systems. They have identified the same molecular mecha- 
nisms in insects as that of mammals. Insects-mainly social insects-are amenable models to study specific gut microbes in behavioural dysfunctions [6]. The gut microbiota secretes various neuroactive compounds to modulate brain functions. It has been suggested that an episode of microbial dysbiosis could lead to social dysfunctions, like schizophrenia and autism spectrum disorders (ASD) [182,183]. Insect intestine-associated microbiota contribute to its cognition, development, social interactions, and chemical communication. By altering the odorant profile of insects, gut microbes alter their behaviours, such as aggregation, mating, and foraging [184-188]. The profound influence of gut-associated microbes has been discovered in insects' neurophysiological development of cognition, such as learning and memorisation. A parkin gene from Drosophila has been linked to Parkinson's disease in humans [4]. The Drosophila model has been successfully utilised to study Alzheimer's disease, and its symptoms were ameliorated in flies by a probiotic supplementation with Lactobacillus and Bifidobacterium strains [189].

Furthermore, researchers have established a link between the reduced expression of histone demethylase KDM5 genes (associated with ASD symptoms) and the alteration in the gut microbiota composition in a Drosophila model. These ASD symptoms can be rescued in flies by probiotic supplementations with Lactobacillus strains [190]. The future outlook should be disentangling the evolutionary origin of the gut microbiota-brain axis and finding suitable probiotics to cure cognitive and behavioural dysfunctions.

\section{Insect Symbiosis: Implication and Outlook}

Insects being the largest and most diversified group on Earth drives several significant roles in the ecosystem. They harbour an astonishing array of microbial communities. The overwhelming impact of microbes on insect functions, ecology, and evolution has gained immense attention recently. Their intimate associations with insect physiology, behaviours, and reproduction have enormously changed our perspective. Understanding the strategy deployed by microbes to manipulate insect hosts would unearth new bioactive molecules, having great potential in medicine [191]. As insects are severe agricultural and forest pests and carriers of vector-borne diseases, unravelling pest insects as holobionts will be of great potential in future IPMs. With Wolbachia being the leading one, paratransgenesis (engineering multiple blocking factors into one microbial species) is an impressive tool for vector-borne disease control [127]. Lately, the influence of insect gut microbiota on dsRNA treatment has also been observed. The synergistic effect of the microbiome on RNAimediated insect pest control has opened up a new avenue of research [192]. The insect gut microbiome can also serve as carriers for dsRNA delivery (SMR: symbiont-mediated RNAi), leading to the sustainable and species-specific delivery of RNA interference [193]. The elucidation of the gut microbiota-brain axis has established insects as potential models for decoding the role of microbes in neurological dysfunctions and their possible probiotic treatment [6]. Future studies on resident microbes within insects using advanced omics approaches such as metatranscriptomics, metaproteomics and metametabolomics will unravel the molecular exchanges underlying symbiosis in model and non-model insects and, thus, shed light on their eco-evolutionary implications in greater depth.

Author Contributions: Conceptualisation, S.S., A.S., I.K.S. and A.C.; investigation, S.S., A.S., V.B., A.R., I.K.S. and A.C.; writing-original draft preparation, S.S. and A.S.; writing-review and editing, S.S., A.S., A.R., V.B., I.K.S. and A.C.; data curation, S.S., A.S., A.R. and A.C.; visualisation, S.S., A.S., V.B., A.R. and I.K.S.; formal analysis, S.S., A.S., A.R. and I.K.S.; funding acquisition, A.C. and A.R.; resources, I.K.S. and A.S.; and supervision, I.K.S., A.C. and A.S. All authors have read and agreed to the published version of the manuscript.

Funding: This project was funded by the Internal Grant Agency, Project ID: B_20_01. AC and AR were supported by “EVA 4.0," No. CZ.02.1.01/0.0/0.0/16_019/0000803, financed by OP RDE. AR was also supported by "EXTEMIT - K", No. CZ.02.1.01/0.0/0.0/15_003/0000433, financed by OP RDE.

Institutional Review Board Statement: Not applicable. 
Informed Consent Statement: Not applicable.

Data Availability Statement: The data presented in this study are available in this article only.

Acknowledgments: The authors, S.S., A.S., and I.K.S, would like to acknowledge the SERB and DST, Govt. of India for the NPDF, ECRA and YSS projects, and author (I.K.S.) is thankful to DBT, Govt. of India for the DBT Star Scheme Project.

Conflicts of Interest: The authors declare no conflict of interest.

\begin{abstract}
Abbreviations
PM: peritrophic matrix; PCR: polymerase chain reaction; Imd: immune deficiency (Imd) pathway; Duox-ROS: dual oxidase-reactive oxygen species; DAP-PGN: Diaminopimelic acid (DAP)-type peptidoglycan (PGN); PGRP: PGN recognition peptide; AMPs: antimicrobial peptides; Dome: domeless; Hop: hopscotch; Upd: unpaired; TRAF3: tumour necrosis factor receptor (TNFR)-associated factor 3; JAK-STAT: Janus kinases (JAKs), signal transducer and activator of transcription proteins (STATs) and receptors; CI: cytoplasmic incompatibility; ROS: reactive oxygen species; PGRPs: pathogen recognition proteins; PIMS: PGRP-LC-interacting inhibitor of Imd signalling; mosGCTLs: mosquito galactose-specific C-type lectins; PRRs: pattern recognition receptors; IMPer: immunomodulatory peroxidase; DENV: Dengue virus; CHIKV: Chikungunya virus; WNV: West Nile virus; ASD: autism spectrum disorders; and SMR: symbiont-mediated RNAi.
\end{abstract}

\title{
References
}

1. $\quad$ Eckburg, P.B.; Bik, E.M.; Bernstein, C.N.; Purdom, E.; Dethlefsen, L.; Sargent, M.; Gill, S.R.; Nelson, K.E.; Relman, D.A. Microbiology: Diversity of the human intestinal microbial flora. Science 2005, 308, 1635-1638. [CrossRef]

2. Metzker, M.L. Sequencing technologies the next generation. Nat. Rev. Genet. 2010, 11, 31-46. [CrossRef]

3. Shpigler, H.Y.; Saul, M.C.; Corona, F.; Block, L.; Ahmed, A.C.; Zhao, S.D.; Robinson, G.E. Erratum: Deep evolutionary conservation of autism-related genes. Proc. Natl. Acad. Sci. USA 2019, 116, 17600. [CrossRef]

4. Feltzin, V.; Wan, K.; Celniker, S.; Bonini, N. Role and impact of the gut microbiota in a Drosophila model for parkinsonism. bioRxiv 2019, 718825. [CrossRef]

5. De Cock, M.; Virgilio, M.; Vandamme, P.; Augustinos, A.; Bourtzis, K.; Willems, A.; De Meyer, M. Impact of sample preservation and manipulation on insect gut microbiome profiling. A Test Case With Fruit Flies (Diptera, Tephritidae). Front. Microbiol. 2019, 10, 2833. [CrossRef] [PubMed]

6. Liberti, J.; Engel, P. The gut microbiota-Brain axis of insects. Curr. Opin. Insect Sci. 2020, 39, 6-13. [CrossRef] [PubMed]

7. Round, J.L.; O'Connell, R.M.; Mazmanian, S.K. Coordination of tolerogenic immune responses by the commensal microbiota. J. Autoimmun. 2010, 34, J220-J225. [CrossRef] [PubMed]

8. Levy, M.; Kolodziejczyk, A.A.; Thaiss, C.A.; Elinav, E. Dysbiosis and the immune system. Nat. Rev. Immunol. 2017, 17, 219-232. [CrossRef]

9. Frago, E.; Dicke, M.; Godfray, H.C.J. Insect symbionts as hidden players in insect-plant interactions. Trends Ecol. Evol. 2012, 27, 705-711. [CrossRef]

10. Engel, P.; Moran, N.A. The gut microbiota of insects-diversity in structure and function. FEMS Microbiol. Rev. 2013, 37, 699-735. [CrossRef]

11. Oliver, K.M.; Martinez, A.J. How resident microbes modulate ecologically-important traits of insects. Curr. Opin. Insect Sci. 2014, 4, 1-7. [CrossRef] [PubMed]

12. Lewis, Z.; Lizé, A. Insect behaviour and the microbiome. Curr. Opin. Insect Sci. 2015, 9, 86-90. [CrossRef] [PubMed]

13. Douglas, A.E. Multiorganismal insects: Diversity and function of resident microorganisms. Annu. Rev. Entomol. 2015, 60, 17-34. [CrossRef]

14. Jing, T.Z.; Qi, F.H.; Wang, Z.Y. Most dominant roles of insect gut bacteria: Digestion, detoxification, or essential nutrient provision? Microbiome 2020, 8, 38. [CrossRef] [PubMed]

15. Weiss, B.; Aksoy, S. Microbiome influences on insect host vector competence. Trends Parasitol. 2011, 27, 514-522. [CrossRef]

16. Hosokawa, T.; Kikuchi, Y.; Shimada, M.; Fukatsu, T. Obligate symbiont involved in pest status of host insect. Proc. R. Soc. B Biol. Sci. 2007, 274, 1979-1984. [CrossRef]

17. Nikoh, N.; Hosokawa, T.; Oshima, K.; Hattori, M.; Fukatsu, T. Reductive evolution of bacterial genome in insect gut environment. Genome Biol. Evol. 2011, 3, 702-714. [CrossRef]

18. Tsuchida, T.; Koga, R.; Matsumoto, S.; Fukatsu, T. Interspecific symbiont transfection confers a novel ecological trait to the recipient insect. Biol. Lett. 2011, 7, 245-248. [CrossRef]

19. Barr, K.L.; Hearne, L.B.; Briesacher, S.; Clark, T.L.; Davis, G.E. Microbial symbionts in insects influence down-regulation of defense genes in maize. PLoS ONE 2010, 5, e11339. [CrossRef] 
20. Vorburger, C.; Gehrer, L.; Rodriguez, P. A strain of the bacterial symbiont Regiella insecticola protects aphids against parasitoids. Biol. Lett. 2010, 6, 109-111. [CrossRef]

21. Nikoh, N.; Hosokawa, T.; Moriyama, M.; Oshima, K.; Hattori, M.; Fukatsu, T. Evolutionary origin of insect-Wolbachia nutritional mutualism. Proc. Natl. Acad. Sci. USA 2014, 111, 10257-10262. [CrossRef]

22. Hansen, A.K.; Trumble, J.T.; Stouthamer, R.; Paine, T.D. A New Huanglongbing Species, " Candidatus Liberibacter psyllaurous," found to infect tomato and potato, is vectored by the Psyllid Bactericera cockerelli (Sulc). Appl. Environ. Microbiol. 2008, 74, 5862-5865. [CrossRef] [PubMed]

23. Casteel, C.L.; Hansen, A.K.; Walling, L.L.; Paine, T.D. Manipulation of plant defense responses by the tomato psyllid (Bactericerca cockerelli) and its associated endosymbiont Candidatus Liberibacter Psyllaurous. PLoS ONE 2012, 7, e35191. [CrossRef]

24. Kaiser, W.; Huguet, E.; Casas, J.; Commin, C.; Giron, D. Plant green-island phenotype induced by leaf-miners is mediated by bacterial symbionts. Proc. R. Soc. B Biol. Sci. 2010, 277, 2311-2319. [CrossRef]

25. Morin, S.; Ghanim, M.; Zeidan, M.; Czosnek, H.; Verbeek, M.; van den Heuvel, J.F.J.M. A GroEL homologue from endosymbiotic bacteria of the whitefly Bemisia tabaci Is implicated in the circulative transmission of tomato yellow leaf curl virus. Virology 1999, 256, 75-84. [CrossRef] [PubMed]

26. Gottlieb, Y.; Zchori-Fein, E.; Mozes-Daube, N.; Kontsedalov, S.; Skaljac, M.; Brumin, M.; Sobol, I.; Czosnek, H.; Vavre, F.; Fleury, F.; et al. The transmission efficiency of tomato yellow leaf curl virus by the whitefly Bemisia tabaci Is Correlated with the Presence of a Specific Symbiotic Bacterium Species. J. Virol. 2010, 84, 9310-9317. [CrossRef]

27. Klein, A.; Schrader, L.; Gil, R.; Manzano-Marín, A.; Flórez, L.; Wheeler, D.; Werren, J.H.; Latorre, A.; Heinze, J.; Kaltenpoth, M.; et al. A novel intracellular mutualistic bacterium in the invasive ant Cardiocondyla obscurior. ISME J. 2016, 10, 376-388. [CrossRef]

28. Oliver, K.M.; Russell, J.A.; Moran, N.A.; Hunter, M.S. Facultative bacterial symbionts in aphids confer resistance to parasitic wasps. Proc. Natl. Acad. Sci. USA 2003, 100, 1803-1807. [CrossRef] [PubMed]

29. Scarborough, C.L. Aphid Protected from pathogen by endosymbiont. Science 2005, 310, 1781. [CrossRef]

30. Kikuchi, Y.; Hayatsu, M.; Hosokawa, T.; Nagayama, A.; Tago, K.; Fukatsu, T. Symbiont-mediated insecticide resistance. Proc. Natl. Acad. Sci. USA 2012, 109, 8618-8622. [CrossRef]

31. McCutcheon, J.P.; McDonald, B.R.; Moran, N.A. Convergent evolution of metabolic roles in bacterial co-symbionts of insects. Proc. Natl. Acad. Sci. USA 2009, 106, 15394-15399. [CrossRef]

32. Shigenobu, S.; Watanabe, H.; Hattori, M.; Sakaki, Y.; Ishikawa, H. Genome sequence of the endocellular bacterial symbiont of aphids Buchnera sp. APS. Nature 2000, 407, 81-86. [CrossRef]

33. Weiss, B.L.; Wang, J.; Aksoy, S. Tsetse immune system maturation requires the presence of obligate symbionts in larvae. PLoS Biol. 2011, 9, e1000619. [CrossRef]

34. Dale, C.; Welburn, S. The endosymbionts of tsetse flies: Manipulating host-parasite interactions. Int. J. Parasitol. 2001, 31, 628-631. [CrossRef]

35. Pons, I.; Renoz, F.; Noël, C.; Hance, T. Circulation of the cultivable symbiont Serratia symbiotica in Aphids Is Mediated by Plants. Front. Microbiol. 2019, 10, 764. [CrossRef]

36. Bando, H.; Okado, K.; Guelbeogo, W.M.; Badolo, A.; Aonuma, H.; Nelson, B.; Fukumoto, S.; Xuan, X.; Sagnon, N.; Kanuka, H. Intra-specific diversity of Serratia marcescens in Anopheles mosquito midgut defines Plasmodium transmission capacity. Sci. Rep. 2013, 3, 1641. [CrossRef] [PubMed]

37. Colgan, L.J.; Erbilgin, N. Tree-mediated interactions between the jack pine budworm and a mountain pine beetle fungal associate. Ecol. Entomol. 2011, 36, 425-434. [CrossRef]

38. Adams, A.S.; Six, D.L. Detection of host habitat by parasitoids using cues associated with mycangial fungi of the mountain pine beetle, Dendroctonus ponderosae. Can. Entomol. 2008, 140, 124-127. [CrossRef]

39. DiGuistini, S.; Wang, Y.; Liao, N.Y.; Taylor, G.; Tanguay, P.; Feau, N.; Henrissat, B.; Chan, S.K.; Hesse-Orce, U.; Alamouti, S.M.; et al. Genome and transcriptome analyses of the mountain pine beetle-fungal symbiont Grosmannia clavigera, a lodgepole pine pathogen. Proc. Natl. Acad. Sci. USA 2011, 108, 2504-2509. [CrossRef] [PubMed]

40. Hulcr, J.; Mann, R.; Stelinski, L.L. The scent of a partner: Ambrosia beetles are attracted to volatiles from their fungal symbionts. J. Chem. Ecol. 2011, 37, 1374-1377. [CrossRef]

41. Kopac, S.M.; Klassen, J.L. Can they make it on their own? Hosts, microbes, and the holobiont niche. Front. Microbiol. 2016, 7, 1647. [CrossRef]

42. Borges, R.M. Co-niche construction between hosts and symbionts: Ideas and evidence. J. Genet. 2017, 96, 483-489. [CrossRef] [PubMed]

43. Trumbo, S.; Klassen, J. Editorial overview: Hidden players: Microbes reshape the insect niche. Curr. Opin. Insect Sci. 2020, 39, vi-ix. [CrossRef] [PubMed]

44. Currie, C.R.; Poulsen, M.; Mendenhall, J.; Boomsma, J.J.; Billen, J. Coevolved crypts and exocrine glands support mutualistic bacteria in fungus-growing ants. Science 2006, 311, 81-83. [CrossRef]

45. Hulcr, J.; Rountree, N.R.; Diamond, S.E.; Stelinski, L.L.; Fierer, N.; Dunn, R.R. Mycangia of Ambrosia Beetles Host Communities of Bacteria. Microb. Ecol. 2012, 64, 784-793. [CrossRef]

46. Yek, S.H.; Mueller, U.G. The metapleural gland of ants. Biol. Rev. 2011, 86, 774-791. [CrossRef]

47. Mason, C.J. Complex Relationships at the intersection of insect gut microbiomes and plant defenses. J. Chem. Ecol. 2020, 46, 793-807. [CrossRef] [PubMed] 
48. Calusinska, M.; Marynowska, M.; Bertucci, M.; Untereiner, B.; Klimek, D.; Goux, X.; Sillam-Dussès, D.; Gawron, P.; Halder, R.; Wilmes, P.; et al. Integrative omics analysis of the termite gut system adaptation to Miscanthus diet identifies lignocellulose degradation enzymes. Commun. Biol. 2020, 3, 275. [CrossRef]

49. Větrovský, T.; Soukup, P.; Stiblik, P.; Votýpková, K.; Chakraborty, A.; Larrañaga, I.O.; Sillam-Dussès, D.; Lo, N.; Bourguignon, T.; Baldrian, P.; et al. Termites host specific fungal communities that differ from those in their ambient environments. Fungal Ecol. 2020, 48, 100991. [CrossRef]

50. Soukup, P.; Větrovský, T.; Stiblik, P.; Votýpková, K.; Chakraborty, A.; Sillam-Dussès, D.; Kolařík, M.; Odriozola, I.; Lo, N.; Baldrian, P.; et al. Termites are associated with external species-specific bacterial communities. Appl. Environ. Microbiol. 2021, 87, e02042-20. [CrossRef]

51. Edwards, M.J.; Jacobs-Lorena, M. Permeability and disruption of the peritrophic matrix and caecal membrane from Aedes aegypti and Anopheles gambiae mosquito larvae. J. Insect Physiol. 2000, 46, 1313-1320. [CrossRef]

52. Pauchet, Y.; Muck, A.; Svatoš, A.; Heckel, D.G.; Preiss, S. Mapping the larval midgut lumen proteome of Helicoverpa armigera, a generalist herbivorous insect. J. Proteome Res. 2008, 7, 1629-1639. [CrossRef]

53. Smith, T.E.; Moran, N.A. Coordination of host and symbiont gene expression reveals a metabolic tug-of-war between aphids and Buchnera. Proc. Natl. Acad. Sci. USA 2020, 117, 2113-2121. [CrossRef] [PubMed]

54. Chen, B.; Teh, B.S.; Sun, C.; Hu, S.; Lu, X.; Boland, W.; Shao, Y. Biodiversity and activity of the gut microbiota across the life history of the insect herbivore Spodoptera littoralis. Sci. Rep. 2016, 6, 29505. [CrossRef] [PubMed]

55. Ceja-Navarro, J.A.; Nguyen, N.H.; Karaoz, U.; Gross, S.R.; Herman, D.J.; Andersen, G.L.; Bruns, T.D.; Pett-Ridge, J.; Blackwell, M.; Brodie, E.L. Compartmentalized microbial composition, oxygen gradients and nitrogen fixation in the gut of Odontotaenius disjunctus. ISME J. 2014, 8, 6-18. [CrossRef] [PubMed]

56. Chung, S.H.; Scully, E.D.; Peiffer, M.; Geib, S.M.; Rosa, C.; Hoover, K.; Felton, G.W. Host plant species determines symbiotic bacterial community mediating suppression of plant defenses. Sci. Rep. 2017, 7, 39690. [CrossRef]

57. Ivens, A.B.F.; Gadau, A.; Kiers, E.T.; Kronauer, D.J.C. Can social partnerships influence the microbiome? Insights from ant farmers and their trophobiont mutualists. Mol. Ecol. 2018, 27, 1898-1914. [CrossRef]

58. Lucas, J.M.; Madden, A.A.; Penick, C.A.; Epps, M.J.; Marting, P.R.; Stevens, J.L.; Fergus, D.J.; Dunn, R.R.; Meineke, E.K. Azteca ants maintain unique microbiomes across functionally distinct nest chambers. Proc. R. Soc. B Biol. Sci. 2019, 286, 20191026. [CrossRef]

59. Bai, S.; Yao, Z.; Raza, M.F.; Cai, Z.; Zhang, H. Regulatory mechanisms of microbial homeostasis in insect gut. Insect Sci. 2021, 28, 286-301. [CrossRef]

60. Chakraborty, A.; Roy, A. Microbial influence on plant-insect interaction. In Plant-Pest Interactions: From Molecular Mechanisms to Chemical Ecology; Springer: Singapore, 2021; pp. 337-363.

61. Hammer, T.J.; Bowers, M.D. Gut microbes may facilitate insect herbivory of chemically defended plants. Oecologia 2015, 179, 1-14. [CrossRef]

62. Jones, A.G.; Mason, C.J.; Felton, G.W.; Hoover, K. Host plant and population source drive diversity of microbial gut communities in two polyphagous insects. Sci. Rep. 2019, 9, 2792. [CrossRef]

63. Mason, C.J.; Rubert-Nason, K.F.; Lindroth, R.L.; Raffa, K.F. Aspen defense chemicals influence midgut bacterial community composition of gypsy moth. J. Chem. Ecol. 2015, 41, 75-84. [CrossRef]

64. Hammer, T.J.; Janzen, D.H.; Hallwachs, W.; Jaffe, S.P.; Fierer, N. Caterpillars lack a resident gut microbiome. Proc. Natl. Acad. Sci. USA 2017, 114, 9641-9646. [CrossRef]

65. Mason, C.J.; Hoover, K.; Felton, G.W. Effects of maize (Zea mays) genotypes and microbial sources in shaping fall armyworm (Spodoptera frugiperda) gut bacterial communities. Sci. Rep. 2021, 11, 4429. [CrossRef]

66. Casteel, C.L.; Hansen, A.K. Evaluating insect-microbiomes at the plant-insect interface. J. Chem. Ecol. 2014, 40, 836-847. [CrossRef]

67. Ceja-Navarro, J.A.; Vega, F.E.; Karaoz, U.; Hao, Z.; Jenkins, S.; Lim, H.C.; Kosina, P.; Infante, F.; Northen, T.R.; Brodie, E.L. Gut microbiota mediate caffeine detoxification in the primary insect pest of coffee. Nat. Commun. 2015, 6, 7618. [CrossRef]

68. Mason, C.J.; Ray, S.; Shikano, I.; Peiffer, M.; Jones, A.G.; Luthe, D.S.; Hoover, K.; Felton, G.W. Plant defenses interact with insect enteric bacteria by initiating a leaky gut syndrome. Proc. Natl. Acad. Sci. USA 2019, 116, 15991-15996. [CrossRef] [PubMed]

69. Van den Bosch, T.J.M.; Welte, C.U. Detoxifying symbionts in agriculturally important pest insects. Microb. Biotechnol. 2017, 10, 531-540. [CrossRef]

70. Berasategui, A.; Salem, H.; Paetz, C.; Santoro, M.; Gershenzon, J.; Kaltenpoth, M.; Schmidt, A. Gut microbiota of the pine weevil degrades conifer diterpenes and increases insect fitness. Mol. Ecol. 2017, 26, 4099-4110. [CrossRef] [PubMed]

71. Itoh, H.; Tago, K.; Hayatsu, M.; Kikuchi, Y. Detoxifying symbiosis: Microbe-mediated detoxification of phytotoxins and pesticides in insects. Nat. Prod. Rep. 2018, 35, 434-454. [CrossRef] [PubMed]

72. De Fine Licht, H.H.; Schitøt, M.; Rogowska-Wrzesinska, A.; Nygaard, S.; Roepstorff, P.; Boomsma, J.J. Laccase detoxification mediates the nutritional alliance between leaf-cutting ants and fungus-garden symbionts. Proc. Natl. Acad. Sci. USA 2013, 110, 583-587. [CrossRef]

73. Welte, C.U.; de Graaf, R.M.; van den Bosch, T.J.M.; Op den Camp, H.J.M.; van Dam, N.M.; Jetten, M.S.M. Plasmids from the gut microbiome of cabbage root fly larvae encode SaxA that catalyses the conversion of the plant toxin 2-phenylethyl isothiocyanate. Environ. Microbiol. 2016, 18, 1379-1390. [CrossRef] [PubMed] 
74. Xia, X.; Gurr, G.M.; Vasseur, L.; Zheng, D.; Zhong, H.; Qin, B.; Lin, J.; Wang, Y.; Song, F.; Li, Y.; et al. Metagenomic sequencing of diamondback moth gut microbiome unveils key holobiont adaptations for herbivory. Front. Microbiol. 2017, 8, 663. [CrossRef]

75. Chakraborty, A.; Ashraf, M.Z.; Modlinger, R.; Synek, J.; Schlyter, F.; Roy, A. Unravelling the gut bacteriome of Ips (Coleoptera: Curculionidae: Scolytinae): Identifying core bacterial assemblage and their ecological relevance. Sci. Rep. 2020, $10,18572$. [CrossRef]

76. Chakraborty, A.; Modlinger, R.; Ashraf, M.Z.; Synek, J.; Schlyter, F.; Roy, A. Core Mycobiome and Their Ecological Relevance in the Gut of Five Ips Bark Beetles (Coleoptera: Curculionidae: Scolytinae). Front. Microbiol. 2020, 11, 568853. [CrossRef]

77. Hammerbacher, A.; Schmidt, A.; Wadke, N.; Wright, L.P.; Schneider, B.; Bohlmann, J.; Brand, W.A.; Fenning, T.M.; Gershenzon, J.; Paetz, C. A common fungal associate of the spruce bark beetle metabolizes the stilbene defenses of Norway spruce. Plant Physiol. 2013, 162, 1324-1336. [CrossRef]

78. Guo, Z.; Lu, Y.; Yang, F.; Zeng, L.; Liang, G.; Xu, Y. Transmission modes of a pesticide-degrading symbiont of the oriental fruit fly Bactrocera dorsalis (Hendel). Appl. Microbiol. Biotechnol. 2017, 101, 8543-8556. [CrossRef] [PubMed]

79. Cheng, D.; Guo, Z.; Riegler, M.; Xi, Z.; Liang, G.; Xu, Y. Gut symbiont enhances insecticide resistance in a significant pest, the oriental fruit fly Bactrocera dorsalis (Hendel). Microbiome 2017, 5, 13. [CrossRef] [PubMed]

80. Ramya, S.L.; Venkatesan, T.; Murthy, K.S.; Jalali, S.K.; Varghese, A. Degradation of acephate by Enterobacter asburiae, Bacillus cereus and Pantoea agglomerans isolated from diamondback moth Plutella xylostella (L), a pest of cruciferous crops. J. Environ. Biol. 2016, 37, 611-618.

81. De Almeida, L.G.; De Moraes, L.A.B.; Trigo, J.R.; Omoto, C.; Cônsoli, F.L. The gut microbiota of insecticide-resistant insects houses insecticide-degrading bacteria: A potential source for biotechnological exploitation. PLoS ONE 2017, 12, e0174754. [CrossRef] [PubMed]

82. Abe, H.; Tomitaka, Y.; Shimoda, T.; Seo, S.; Sakurai, T.; Kugimiya, S.; Tsuda, S.; Kobayashi, M. Antagonistic plant defense system regulated by phytohormones assists interactions among vector insect, thrips and a tospovirus. Plant Cell Physiol. 2012, 53, 204-212. [CrossRef]

83. Chung, S.H.; Rosa, C.; Scully, E.D.; Peiffer, M.; Tooker, J.F.; Hoover, K.; Luthe, D.S.; Felton, G.W. Herbivore exploits orally secreted bacteria to suppress plant defenses. Proc. Natl. Acad. Sci. USA 2013, 110, 15728-15733. [CrossRef]

84. Wang, J.; Chung, S.H.; Peiffer, M.; Rosa, C.; Hoover, K.; Zeng, R.; Felton, G.W. Herbivore oral secreted bacteria trigger distinct defense responses in preferred and non-preferred host plants. J. Chem. Ecol. 2016, 42, 463-474. [CrossRef]

85. Yamasaki, Y.; Sumioka, H.; Takiguchi, M.; Uemura, T.; Kihara, Y.; Shinya, T.; Galis, I.; Arimura, G. Phytohormone-dependent plant defense signaling orchestrated by oral bacteria of the herbivore Spodoptera litura. New Phytol. 2021, 231, 2029-2038. [CrossRef] [PubMed]

86. Spiteller, D.; Dettner, K.; Boland, W. Gut bacteria may be involved in interactions between plants, herbivores and their predators: Microbial biosynthesis of N-acylglutamine surfactants as elicitors of plant volatiles. Biol. Chem. 2000, 381, 755-762. [CrossRef]

87. Hill, C.A.; Kafatos, F.C.; Stansfield, S.K.; Collins, F.H. Arthropod-borne diseases: Vector control in the genomics era. Nat. Rev. Microbiol. 2005, 3, 262-268. [CrossRef] [PubMed]

88. Cirimotich, C.M.; Dong, Y.; Garver, L.S.; Sim, S.; Dimopoulos, G. Mosquito immune defenses against Plasmodium infection. Dev. Comp. Immunol. 2010, 34, 387-395. [CrossRef]

89. Xi, Z.; Ramirez, J.L.; Dimopoulos, G. The Aedes aegypti toll pathway controls dengue virus infection. PLoS Pathog. 2008, 4, e1000098. [CrossRef]

90. Minard, G.; Mavingui, P.; Moro, C.V. Diversity and function of bacterial microbiota in the mosquito holobiont. Parasites Vectors 2013, 6, 146. [CrossRef]

91. Mereghetti, V.; Chouaia, B.; Montagna, M. New insights into the microbiota of moth pests. Int. J. Mol. Sci. 2017, 18, 2450. [CrossRef] [PubMed]

92. Guégan, M.; Zouache, K.; Démichel, C.; Minard, G.; Tran Van, V.; Potier, P.; Mavingui, P.; Valiente Moro, C. The mosquito holobiont: Fresh insight into mosquito-microbiota interactions. Microbiome 2018, 6, 49. [CrossRef]

93. Strand, M.R. Composition and functional roles of the gut microbiota in mosquitoes. Curr. Opin. Insect Sci. 2018, 28 , 59-65. [CrossRef] [PubMed]

94. Degnan, P.H.; Lazarus, A.B.; Wernegreen, J.J. Genome sequence of Blochmannia pennsylvanicus indicates parallel evolutionary trends among bacterial mutualists of insects. Genome Res. 2005, 15, 1023-1033. [CrossRef]

95. Akman, L.; Yamashita, A.; Watanabe, H.; Oshima, K.; Shiba, T.; Hattori, M.; Aksoy, S. Genome sequence of the endocellular obligate symbiont of tsetse flies, Wigglesworthia glossinidia. Nat. Genet. 2002, 32, 402-407. [CrossRef]

96. Degnan, P.H.; Yu, Y.; Sisneros, N.; Wing, R.A.; Moran, N.A. Hamiltonella defensa, genome evolution of protective bacterial endosymbiont from pathogenic ancestors. Proc. Natl. Acad. Sci. USA 2009, 106, 9063-9068. [CrossRef]

97. Akman, L.; Rio, R.V.M.; Beard, C.B.; Aksoy, S. Genome size determination and coding capacity of Sodalis glossinidius, an enteric symbiont of tsetse flies, as revealed by hybridization to Escherichia coli gene arrays. J. Bacteriol. 2001, 183, 4517-4525. [CrossRef]

98. Hoffmann, A.A.; Clancy, D.; Duncan, J. Naturally-occurring Wolbachia infection in Drosophila simulans that does not cause cytoplasmic incompatibility. Heredity 1996, 76, 1-8. [CrossRef]

99. Reynolds, K.T.; Hoffmann, A.A. Male age, host effects and the weak expression or non-expression of cytoplasmic incompatibility in Drosophila strains infected by maternally transmitted Wolbachia. Genet. Res. 2002, 80, 79-87. [CrossRef] [PubMed] 
100. Fry, A.J.; Palmer, M.R.; Rand, D.M. Variable fitness effects of Wolbachia infection in Drosophila melanogaster. Heredity 2004, 93, 379-389. [CrossRef] [PubMed]

101. Brownlie, J.C.; Cass, B.N.; Riegler, M.; Witsenburg, J.J.; Iturbe-Ormaetxe, I.; McGraw, E.A.; O’Neill, S.L. Evidence for metabolic provisioning by a common invertebrate endosymbiont, Wolbachia pipientis, during periods of nutritional stress. PLoS Pathog. 2009, 5, e1000368. [CrossRef]

102. Kremer, N.; Voronin, D.; Charif, D.; Mavingui, P.; Mollereau, B.; Vavre, F. Wolbachia interferes with ferritin expression and iron metabolism in insects. PLoS Pathog. 2009, 5, e1000630. [CrossRef]

103. Ikeya, T.; Broughton, S.; Alic, N.; Grandison, R.; Partridge, L. The endosymbiont Wolbachia increases insulin/IGF-like signalling in Drosophila. Proc. R. Soc. B Biol. Sci. 2009, 276, 3799-3807. [CrossRef]

104. Moreira, L.A.; Iturbe-Ormaetxe, I.; Jeffery, J.A.; Lu, G.; Pyke, A.T.; Hedges, L.M.; Rocha, B.C.; Hall-Mendelin, S.; Day, A.; Riegler, M.; et al. A Wolbachia Symbiont in Aedes aegypti Limits Infection with Dengue, Chikungunya, and Plasmodium. Cell 2009, 139, 1268-1278. [CrossRef]

105. Bian, G.; Xu, Y.; Lu, P.; Xie, Y.; Xi, Z. The Endosymbiotic bacterium Wolbachia induces resistance to dengue virus in Aedes aegypti. PLoS Pathog. 2010, 6, e1000833. [CrossRef] [PubMed]

106. Glaser, R.L.; Meola, M.A. The native Wolbachia Endosymbionts of Drosophila melanogaster and Culex quinquefasciatus increase host resistance to west nile virus infection. PLoS ONE 2010, 5, e11977. [CrossRef]

107. Nazni, W.A.; Hoffmann, A.A.; NoorAfizah, A.; Cheong, Y.L.; Mancini, M.V.; Golding, N.; Kamarul, G.M.R.; Arif, M.A.K.; Thohir, H.; NurSyamimi, H.; et al. Establishment of Wolbachia strain wAlbB in malaysian populations of aedes aegypti for dengue control. Curr. Biol. 2019, 29, 4241-4248.e5. [CrossRef] [PubMed]

108. Pinto, S.B.; Riback, T.I.S.; Sylvestre, G.; Costa, G.; Peixoto, J.; Dias, F.B.S.; Tanamas, S.K.; Simmons, C.P.; Dufault, S.M.; Ryan, P.A.; et al. Effectiveness of wolbachia-infected mosquito deployments in reducing the incidence of dengue and other aedes-borne diseases in niterói, brazil: A quasi-experimental study. PLoS Negl. Trop. Dis. 2021, 15, e0009556. [CrossRef] [PubMed]

109. Ant, T.H.; Herd, C.S.; Geoghegan, V.; Hoffmann, A.A.; Sinkins, S.P. The Wolbachia strain wAu provides highly efficient virus transmission blocking in Aedes aegypti. PLoS Pathog. 2018, 14, e1006815. [CrossRef]

110. Utarini, A.; Indriani, C.; Ahmad, R.A.; Tantowijoyo, W.; Arguni, E.; Ansari, M.R.; Supriyati, E.; Wardana, D.S.; Meitika, Y.; Ernesia, I.; et al. Efficacy of Wolbachia-infected mosquito deployments for the control of dengue. N. Engl. J. Med. 2021, 384, 2177-2186. [CrossRef]

111. Fraser, J.E.; De Bruyne, J.T.; Iturbe-Ormaetxe, I.; Stepnell, J.; Burns, R.L.; Flores, H.A.; O’Neill, S.L. Novel Wolbachia-transinfected Aedes aegypti mosquitoes possess diverse fitness and vector competence phenotypes. PLoS Pathog. 2017, 13, e1006751. [CrossRef]

112. Zhang, R.; Zhu, Y.; Pang, X.; Xiao, X.; Zhang, R.; Cheng, G. Regulation of antimicrobial peptides in Aedes aegypti Aag2 Cells. Front. Cell. Infect. Microbiol. 2017, 7, 22. [CrossRef]

113. Royet, J.; Dziarski, R. Peptidoglycan recognition proteins: Pleiotropic sensors and effectors of antimicrobial defences. Nat. Rev. Microbiol. 2007, 5, 264-277. [CrossRef] [PubMed]

114. Pang, X.; Xiao, X.; Liu, Y.; Zhang, R.; Liu, J.; Liu, Q.; Wang, P.; Cheng, G. Mosquito C-type lectins maintain gut microbiome homeostasis. Nat. Microbiol. 2016, 1, 16023. [CrossRef] [PubMed]

115. Xiao, X.; Yang, L.; Pang, X.; Zhang, R.; Zhu, Y.; Wang, P.; Gao, G.; Cheng, G. A Mesh-Duox pathway regulates homeostasis in the insect gut. Nat. Microbiol. 2017, 2, 17020. [CrossRef]

116. Oliveira, J.H.M.; Gonçalves, R.L.S.; Lara, F.A.; Dias, F.A.; Gandara, A.C.P.; Menna-Barreto, R.F.S.; Edwards, M.C.; Laurindo, F.R.M.; Silva-Neto, M.A.C.; Sorgine, M.H.F.; et al. Blood meal-derived heme decreases ROS levels in the midgut of Aedes aegypti and allows proliferation of intestinal microbiota. PLoS Pathog. 2011, 7, e1001320. [CrossRef]

117. Diaz-Albiter, H.; Sant'Anna, M.R.V.; Genta, F.A.; Dillon, R.J. Reactive oxygen species-mediated immunity against Leishmania mexicana and Serratia marcescens in the phlebotomine sand fly Lutzomyia longipalpis. J. Biol. Chem. 2012, 287, 23995-24003. [CrossRef]

118. Pan, X.; Zhou, G.; Wu, J.; Bian, G.; Lu, P.; Raikhel, A.S.; Xi, Z. Wolbachia induces reactive oxygen species (ROS)-dependent activation of the Toll pathway to control dengue virus in the mosquito Aedes aegypti. Proc. Natl. Acad. Sci. USA 2012, 109, E23-E31. [CrossRef]

119. Hurst, G.D.D.; Anbutsu, H.; Kutsukake, M.; Fukatsu, T. Hidden from the host: Spiroplasma bacteria infecting Drosophila do not cause an immune response, but are suppressed by ectopic immune activation. Insect Mol. Biol. 2003, 12, 93-97. [CrossRef]

120. Hutchence, K.J.; Fischer, B.; Paterson, S.; Hurst, G.D.D. How do insects react to novel inherited symbionts? A microarray analysis of Drosophila melanogaster response to the presence of natural and introduced Spiroplasma. Mol. Ecol. 2011, 20, 950-958. [CrossRef]

121. Zug, R.; Hammerstein, P. Bad guys turned nice? A critical assessment of Wolbachia mutualisms in arthropod hosts. Biol. Rev. 2015, 90, 89-111. [CrossRef] [PubMed]

122. Kumar, S.; Molina-Cruz, A.; Gupta, L.; Rodrigues, J.; Barillas-Mury, C. A Peroxidase/Dual oxidase system modulates midgut epithelial immunity in Anopheles gambiae. Science 2010, 327, 1644-1648. [CrossRef]

123. Louis, C.; Nigro, L. Ultrastructural evidence of Wolbachia rickettsiales in Drosophila simulans and their relationships with unidirectional cross-incompatibility. J. Invertebr. Pathol. 1989, 54, 39-44. [CrossRef]

124. Zug, R.; Hammerstein, P. Wolbachia and the insect immune system: What reactive oxygen species can tell us about the mechanisms of Wolbachia-host interactions. Front. Microbiol. 2015, 6, 1201. [CrossRef] 
125. Cleton, N.; Koopmans, M.; Reimerink, J.; Godeke, G.J.; Reusken, C. Come fly with me: Review of clinically important arboviruses for global travelers. J. Clin. Virol. 2012, 55, 191-203. [CrossRef]

126. Moyes, C.L.; Vontas, J.; Martins, A.J.; Ng, L.C.; Koou, S.Y.; Dusfour, I.; Raghavendra, K.; Pinto, J.; Corbel, V.; David, J.-P.; et al. Contemporary status of insecticide resistance in the major Aedes vectors of arboviruses infecting humans. PLoS Negl. Trop. Dis. 2017, 11, e0005625. [CrossRef] [PubMed]

127. Shaw, W.R.; Catteruccia, F. Vector biology meets disease control: Using basic research to fight vector-borne diseases. Nat. Microbiol. 2019, 4, 20-34. [CrossRef]

128. Gonzales-Ceron, L.; Santillan, F.; Rodriguez, M.H.; Mendez, D.; Hernandez-Avila, J.E. Bacteria in midguts of field-collected Anopheles albimanus Block Plasmodium vivax Sporogonic Development. J. Med. Entomol. 2003, 40, 371-374. [CrossRef] [PubMed]

129. Dong, Y.; Aguilar, R.; Xi, Z.; Warr, E.; Mongin, E.; Dimopoulos, G. Anopheles gambiae immune responses to human and rodent Plasmodium parasite species. PLoS Pathog. 2006, 2, 0513-0525. [CrossRef] [PubMed]

130. Dong, Y.; Manfredini, F.; Dimopoulos, G. Implication of the mosquito midgut microbiota in the defense against malaria parasites. PLoS Pathog. 2009, 5, e1000423. [CrossRef] [PubMed]

131. Pais, R.; Lohs, C.; Wu, Y.; Wang, J.; Aksoy, S. The obligate mutualist Wigglesworthia glossinidia influences reproduction, digestion, and immunity processes of its host, the tsetse fly. Appl. Environ. Microbiol. 2008, 74, 5965-5974. [CrossRef]

132. Saraiva, R.G.; Fang, J.; Kang, S.; Angleró-Rodríguez, Y.I.; Dong, Y.; Dimopoulos, G. Aminopeptidase secreted by Chromobacterium sp. Panama inhibits dengue virus infection by degrading the E protein. PLoS Negl. Trop. Dis. 2018, 12, e0006443. [CrossRef]

133. Apte-Deshpande, A.; Paingankar, M.; Gokhale, M.D.; Deobagkar, D.N. Serratia odorifera a midgut inhabitant of aedes aegypti mosquito enhances its susceptibility to dengue-2 virus. PLoS ONE 2012, 7, e40401. [CrossRef]

134. Cirimotich, C.M.; Dong, Y.; Clayton, A.M.; Sandiford, S.L.; Souza-Neto, J.A.; Mulenga, M.; Dimopoulos, G. Natural microbemediated refractoriness to Plasmodium infection in Anopheles gambiae. Science 2011, 332, 855-858. [CrossRef] [PubMed]

135. Narasimhan, S.; Rajeevan, N.; Liu, L.; Zhao, Y.O.; Heisig, J.; Pan, J.; Eppler-Epstein, R.; Deponte, K.; Fish, D.; Fikrig, E. Gut microbiota of the tick vector Ixodes scapularis modulate colonization of the Lyme disease spirochete. Cell Host Microbe 2014, 15, 58-71. [CrossRef] [PubMed]

136. Pruzinova, K.; Sadlova, J.; Seblova, V.; Homola, M.; Votypka, J.; Volf, P. Comparison of bloodmeal digestion and the peritrophic matrix in four sand fly species differing in susceptibility to leishmania donovani. PLoS ONE 2015, 10, e0128203. [CrossRef] [PubMed]

137. Rodgers, F.H.; Gendrin, M.; Wyer, C.A.S.; Christophides, G.K. Microbiota-induced peritrophic matrix regulates midgut homeostasis and prevents systemic infection of malaria vector mosquitoes. PLoS Pathog. 2017, 13, e1006391. [CrossRef]

138. Aksoy, S. Tsetse peritrophic matrix influences for trypanosome transmission. J. Insect Physiol. 2019, 118, 103919. [CrossRef]

139. Wang, J.; Wu, Y.; Yang, G.; Aksoy, S. Interactions between mutualist Wigglesworthia and tsetse peptidoglycan recognition protein (PGRP-LB) influence trypanosome transmission. Proc. Natl. Acad. Sci. USA 2009, 106, 12133-12138. [CrossRef]

140. Rodrigues, J.; Brayner, F.A.; Alves, L.C.; Dixit, R.; Barillas-Mury, C. Hemocyte Differentiation Mediates Innate Immune Memory in Anopheles gambiae Mosquitoes. Science 2010, 329, 1353-1355. [CrossRef]

141. Fraser, J.E.; O’Donnell, T.B.; Duyvestyn, J.M.; O'Neill, S.L.; Simmons, C.P.; Flores, H.A. Novel phenotype of Wolbachia strain wPip in Aedes aegypti challenges assumptions on mechanisms of Wolbachia-mediated dengue virus inhibition. PLoS Pathog. 2020, 16, e1008410. [CrossRef]

142. Lindsey, A.; Bhattacharya, T.; Newton, I.; Hardy, R. Conflict in the intracellular lives of endosymbionts and viruses: A mechanistic look at Wolbachia-Mediated Pathogen-blocking. Viruses 2018, 10, 141. [CrossRef]

143. Hussain, M.; Frentiu, F.D.; Moreira, L.A.; O’Neill, S.L.; Asgari, S. Wolbachia uses host microRNAs to manipulate host gene expression and facilitate colonization of the dengue vector Aedes aegypti. Proc. Natl. Acad. Sci. USA 2011, 108, 9250-9255. [CrossRef]

144. Rancès, E.; Ye, Y.H.; Woolfit, M.; McGraw, E.A.; O'Neill, S.L. The relative importance of innate immune priming in Wolbachiamediated dengue interference. PLoS Pathog. 2012, 8, e1002548. [CrossRef] [PubMed]

145. Lu, P.; Bian, G.; Pan, X.; Xi, Z. Wolbachia induces density-dependent inhibition to dengue virus in mosquito cells. PLoS Negl. Trop. Dis. 2012, 6, e1754. [CrossRef] [PubMed]

146. Zhang, G.; Hussain, M.; O'Neill, S.L.; Asgari, S. Wolbachia uses a host microRNA to regulate transcripts of a methyltransferase, contributing to dengue virus inhibition in Aedes aegypti. Proc. Natl. Acad. Sci. USA 2013, 110, 10276-10281. [CrossRef] [PubMed]

147. Walker, T.; Johnson, P.H.; Moreira, L.A.; Iturbe-Ormaetxe, I.; Frentiu, F.D.; McMeniman, C.J.; Leong, Y.S.; Dong, Y.; Axford, J.; Kriesner, P.; et al. The wMel Wolbachia strain blocks dengue and invades caged Aedes aegypti populations. Nature 2011, 476, 450-453. [CrossRef]

148. Geoghegan, V.; Stainton, K.; Rainey, S.M.; Ant, T.H.; Dowle, A.A.; Larson, T.; Hester, S.; Charles, P.D.; Thomas, B.; Sinkins, S.P. Perturbed cholesterol and vesicular trafficking associated with dengue blocking in Wolbachia-infected Aedes aegypti cells. Nat. Commun. 2017, 8, 526. [CrossRef]

149. Caragata, E.P.; Rancès, E.; Hedges, L.M.; Gofton, A.W.; Johnson, K.N.; O’Neill, S.L.; McGraw, E.A. Dietary cholesterol modulates pathogen blocking by Wolbachia. PLoS Pathog. 2013, 9, e1003459. [CrossRef] [PubMed]

150. Koh, C.; Islam, M.N.; Ye, Y.H.; Chotiwan, N.; Graham, B.; Belisle, J.T.; Kouremenos, K.A.; Dayalan, S.; Tull, D.L.; Klatt, S.; et al. Dengue virus dominates lipid metabolism modulations in Wolbachia-coinfected Aedes aegypti. Commun. Biol. 2020, 3, 518. [CrossRef] [PubMed] 
151. Chotiwan, N.; Andre, B.G.; Sanchez-Vargas, I.; Islam, M.N.; Grabowski, J.M.; Hopf-Jannasch, A.; Gough, E.; Nakayasu, E.; Blair, C.D.; Belisle, J.T.; et al. Dynamic remodeling of lipids coincides with dengue virus replication in the midgut of Aedes aegypti mosquitoes. PLOS Pathog. 2018, 14, e1006853. [CrossRef]

152. Manokaran, G.; Flores, H.A.; Dickson, C.T.; Narayana, V.K.; Kanojia, K.; Dayalan, S.; Tull, D.; McConville, M.J.; Mackenzie, J.M.; Simmons, C.P. Modulation of acyl-carnitines, the broad mechanism behind Wolbachia-mediated inhibition of medically important flaviviruses in Aedes aegypti. Proc. Natl. Acad. Sci. USA 2020, 117, 24475-24483. [CrossRef] [PubMed]

153. Haqshenas, G.; Terradas, G.; Paradkar, P.N.; Duchemin, J.B.; McGraw, E.A.; Doerig, C. A Role for the insulin receptor in the suppression of dengue virus and zika virus in Wolbachia-infected mosquito cells. Cell Rep. 2019, 26, 529-535.e3. [CrossRef]

154. Schooneman, M.G.; Vaz, F.M.; Houten, S.M.; Soeters, M.R. Acylcarnitines. Diabetes 2013, 62, 1-8. [CrossRef] [PubMed]

155. Molloy, J.C.; Sommer, U.; Viant, M.R.; Sinkins, S.P. Wolbachia modulates lipid metabolism in Aedes albopictus mosquito cells. Appl. Environ. Microbiol. 2016, 82, 3109-3120. [CrossRef]

156. O’Neill, S.L.; Ryan, P.A.; Turley, A.P.; Wilson, G.; Hurst, T.P.; Retzki, K.; Brown-Kenyon, J.; Hodgson, L.; Kenny, N.; Cook, H.; et al. Establishment of wMel Wolbachia in Aedes aegypti mosquitoes and reduction of local dengue transmission in Cairns and surrounding locations in northern Queensland, Australia. Gates Open Res. 2019, 3, 1547. [CrossRef]

157. Tantowijoyo, W.; Andari, B.; Arguni, E.; Budiwati, N.; Nurhayati, I.; Fitriana, I.; Ernesia, I.; Daniwijaya, E.W.; Supriyati, E.; Yusdiana, D.H.; et al. Stable establishment of WMEL Wolbachia in Aedes aegypti populations in Yogyakarta, Indonesia. PLoS Negl. Trop. Dis. 2020, 14, e0008157. [CrossRef]

158. Gesto, J.S.M.; Ribeiro, G.S.; Rocha, M.N.; Dias, F.B.S.; Peixoto, J.; Carvalho, F.D.; Pereira, T.N.; Moreira, L.A. Reduced competence to arboviruses following the sustainable invasion of Wolbachia into native Aedes aegypti from Southeastern Brazil. Sci. Rep. 2021, 11, 1-14. [CrossRef]

159. Carr, J.P.; Donnelly, R.; Tungadi, T.; Murphy, A.M.; Jiang, S.; Bravo-Cazar, A.; Yoon, J.Y.; Cunniffe, N.J.; Glover, B.J.; Gilligan, C.A. Viral Manipulation of plant stress responses and host interactions with insects. Adv. Virus Res. 2018, 102, 177-197. [CrossRef]

160. Kaur, N.; Hasegawa, D.K.; Ling, K.S.; Wintermantel, W.M. Application of genomics for understanding plant virus-insect vector interactions and insect vector control. Phytopathology 2016, 106, 1213-1222. [CrossRef]

161. Frank, J.H.; Frank, J.H.; Thomas, M.C.; Yousten, A.A.; Howard, F.W.; Giblin-davis, R.M.; Heppner, J.B.; Zuparko, R.L.; Sánchez, N.E.; Luna, M.G.; et al. Plant Viruses and Insects. In Encyclopedia of Entomology; Springer: Dordrecht, The Netherlands, 2008; pp. 2938-2945.

162. Gong, J.-T.; Li, Y.; Li, T.-P.; Liang, Y.; Hu, L.; Zhang, D.; Zhou, C.-Y.; Yang, C.; Zhang, X.; Zha, S.-S.; et al. Stable introduction of plant-virus-inhibiting Wolbachia into Planthoppers for Rice Protection. Curr. Biol. 2020, 30, 4837-4845. [CrossRef]

163. Ramalho, M.O.; Duplais, C.; Orivel, J.; Dejean, A.; Gibson, J.C.; Suarez, A.V.; Moreau, C.S. Development but not diet alters microbial communities in the Neotropical arboreal trap jaw ant Daceton armigerum: An exploratory study. Sci. Rep. 2020, 10, 7350. [CrossRef]

164. Segers, F.H.I.D.; Kaltenpoth, M.; Foitzik, S. Abdominal microbial communities in ants depend on colony membership rather than caste and are linked to colony productivity. Ecol. Evol. 2019, 9, 13450-13467. [CrossRef]

165. Salem, H.; Bauer, E.; Strauss, A.S.; Vogel, H.; Marz, M.; Kaltenpoth, M. Vitamin supplementation by gut symbionts ensures metabolic homeostasis in an insect host. Proc. R. Soc. B Biol. Sci. 2014, 281, 20141838. [CrossRef] [PubMed]

166. Douglas, A.E. The B vitamin nutrition of insects: The contributions of diet, microbiome and horizontally acquired genes. Curr. Opin. Insect Sci. 2017, 23, 65-69. [CrossRef]

167. Kaltenpoth, M.; Göttler, W.; Herzner, G.; Strohm, E. Symbiotic bacteria protect wasp larvae from fungal infestation. Curr. Biol. 2005, 15, 475-479. [CrossRef]

168. Vizcaino, M.I.; Guo, X.; Crawford, J.M. Merging chemical ecology with bacterial genome mining for secondary metabolite discovery. J. Ind. Microbiol. Biotechnol. 2014, 41, 285-299. [CrossRef]

169. Klassen, J.L. Microbial secondary metabolites and their impacts on insect symbioses. Curr. Opin. Insect Sci. 2014, 4, 15-22. [CrossRef] [PubMed]

170. Hurst, G.D.D.; Frost, C.L. Reproductive parasitism: Maternally inherited symbionts in a biparental world. Cold Spring Harb. Perspect. Biol. 2015, 7, a017699. [CrossRef] [PubMed]

171. Jiggins, F.M.; Hurst, G.D.D.; Majerus, M.E.N. Sex-ratio-distorting Wolbachia causes sex-role reversal in its butterfly host. Proc. R. Soc. B Biol. Sci. 2000, 267, 69-73. [CrossRef]

172. Abe, J.; Kamimura, Y.; Kondo, N.; Shimada, M. Extremely female-biased sex ratio and lethal male-male combat in a parasitoid wasp, Melittobia australica (Eulophidae). Behav. Ecol. 2003, 14, 34-39. [CrossRef]

173. Stouthamer, R.; Breeuwer, J.A.J.; Hurst, G.D.D. Wolbachia pipientis: Microbial manipulator of arthropod reproduction. Annu. Rev. Microbiol. 1999, 53, 71-102. [CrossRef]

174. Mateos, M.; Castrezana, S.J.; Nankivell, B.J.; Estes, A.M.; Markow, T.A.; Moran, N.A. Heritable endosymbionts of Drosophila. Genetics 2006, 174, 363-376. [CrossRef] [PubMed]

175. Goodacre, S.L.; Martin, O.Y.; Thomas, C.F.G.; Hewitt, G.M. Wolbachia and other endosymbiont infections in spiders. Mol. Ecol. 2006, 15, 517-527. [CrossRef]

176. Konecka, E.; Olszanowski, Z. A screen of maternally inherited microbial endosymbionts in oribatid mites (Acari: Oribatida). Microbiology 2015, 161, 1561-1571. [CrossRef] 
177. Kenyon, S.G.; Hunter, M.S. Manipulation of oviposition choice of the parasitoid wasp, Encarsia pergandiella, by the endosymbiotic bacterium Cardinium. J. Evol. Biol. 2007, 20, 707-716. [CrossRef] [PubMed]

178. Hughes, D.P.; Andersen, S.B.; Hywel-Jones, N.L.; Himaman, W.; Billen, J.; Boomsma, J.J. Behavioral mechanisms and morphological symptoms of zombie ants dying from fungal infection. BMC Ecol. 2011, 11, 13. [CrossRef] [PubMed]

179. Zurek, L.; Wes Watson, D.; Krasnoff, S.B.; Schal, C. Effect of the entomopathogenic fungus, Entomophthora muscae (Zygomycetes: Entomophthoraceae), on sex pheromone and other cuticular hydrocarbons of the house fly, Musca domestica. J. Invertebr. Pathol. 2002, 80, 171-176. [CrossRef]

180. Adamo, S.A.; Kovalko, I.; Easy, R.H.; Stoltz, D. A viral aphrodisiac in the cricket Gryllus texensis. J. Exp. Biol. 2014, 217, 1970-1976. [CrossRef]

181. Cheng, D.; Chen, S.; Huang, Y.; Pierce, N.E.; Riegler, M.; Yang, F.; Zeng, L.; Lu, Y.; Liang, G.; Xu, Y. Symbiotic microbiota may reflect host adaptation by resident to invasive ant species. PLOS Pathog. 2019, 15, e1007942. [CrossRef]

182. Sgritta, M.; Dooling, S.W.; Buffington, S.A.; Momin, E.N.; Francis, M.B.; Britton, R.A.; Costa-Mattioli, M. Mechanisms underlying microbial-mediated changes in social behavior in mouse models of autism spectrum disorder. Neuron 2019, 101, 246-259.e6. [CrossRef]

183. Zhu, F.; Guo, R.; Wang, W.; Ju, Y.; Wang, Q.; Ma, Q.; Sun, Q.; Fan, Y.; Xie, Y.; Yang, Z.; et al. Transplantation of microbiota from drug-free patients with schizophrenia causes schizophrenia-like abnormal behaviors and dysregulated kynurenine metabolism in mice. Mol. Psychiatry 2020, 25, 2905-2918. [CrossRef]

184. Wada-Katsumata, A.; Zurek, L.; Nalyanya, G.; Roelofs, W.L.; Zhang, A.; Schal, C. Gut bacteria mediate aggregation in the German cockroach. Proc. Natl. Acad. Sci. USA 2015, 112, 15678-15683. [CrossRef] [PubMed]

185. Wong, A.C.N.; Wang, Q.P.; Morimoto, J.; Senior, A.M.; Lihoreau, M.; Neely, G.G.; Simpson, S.J.; Ponton, F. Gut microbiota modifies olfactory-guided microbial preferences and foraging decisions in Drosophila. Curr. Biol. 2017, 27, 2397-2404.e4. [CrossRef]

186. Carthey, A.J.R.; Gillings, M.R.; Blumstein, D.T. The Extended Genotype: Microbially mediated olfactory communication. Trends Ecol. Evol. 2018, 33, 885-894. [CrossRef] [PubMed]

187. DeNieu, M.; Mounts, K.; Manier, M. Two gut microbes are necessary and sufficient for normal cognition in Drosophila melanogaster. bioRxiv 2019, 593723. [CrossRef]

188. Teseo, S.; van Zweden, J.S.; Pontieri, L.; Kooij, P.W.; Sørensen, S.J.; Wenseleers, T.; Poulsen, M.; Boomsma, J.J.; Sapountzis, P. The scent of symbiosis: Gut bacteria may affect social interactions in leaf-cutting ants. Anim. Behav. 2019, 150, 239-254. [CrossRef]

189. Westfall, S.; Lomis, N.; Prakash, S. A novel synbiotic delays Alzheimer's disease onset via combinatorial gut-brain-axis signaling in Drosophila melanogaster. PLoS ONE 2019, 14, e0214985. [CrossRef]

190. Chen, K.; Luan, X.; Liu, Q.; Wang, J.; Chang, X.; Snijders, A.M.; Mao, J.H.; Secombe, J.; Dan, Z.; Chen, J.H.; et al. Drosophila histone demethylase KDM5 regulates social behavior through immune control and gut microbiota maintenance. Cell Host Microbe 2019, 25, 537-552.e8. [CrossRef]

191. Van Moll, L.; De Smet, J.; Cos, P.; Van Campenhout, L. Microbial symbionts of insects as a source of new antimicrobials: A review. Crit. Rev. Microbiol. 2021, 47, 562-579. [CrossRef]

192. Xu, L.; Xu, S.; Sun, L.; Zhang, Y.; Luo, J.; Bock, R.; Zhang, J. Synergistic action of the gut microbiota in environmental RNA interference in a leaf beetle. Microbiome 2021, 9, 98. [CrossRef]

193. Whitten, M.; Dyson, P. Gene silencing in non-model insects: Overcoming hurdles using symbiotic bacteria for trauma-free sustainable delivery of RNA interference: Sustained RNA interference in insects mediated by symbiotic bacteria: Applications as a genetic tool and as a biocid. BioEssays 2017, 39, 1600247. [CrossRef] [PubMed] 